\title{
KACAPI INDUNG \\ PANGANTEUR DINA CARITA DUA TEU SARASA
}

\author{
SKRIPSI \\ KARYA SENI
}

Untuk memenuhi salah satu syarat tugas akhir

Program Sarjana Seni

Program Studi Seni Karawitan

OLEH

AGUS DIANTARA

15123005

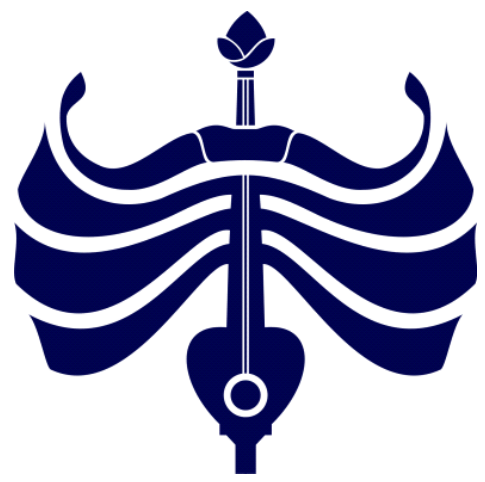

PROGRAM STUDI SENI KARAWITAN

FAKULTAS SENI PERTUNJUKAN

INSTITUT SENI BUDAYA INDONESIA BANDUNG 2019 


\title{
HALAMAN PERSETUJUAN
}

\author{
SKRIPSI \\ KARYA SENI
}

\section{KACAPI INDUNG PANGANTEUR DINA CARITA DUA TEU SARASA}

\section{Diajukan oleh}

AGUS DIANTARA

15123005

Disetujui oleh pembimbing untuk mengikuti ujian akhir

Pada program studi Seni Karawitan

Fakultas Seni Pertunjukan ISBI Bandung

\section{Bandung, 26 Juni 2019}

Pembimbing 1

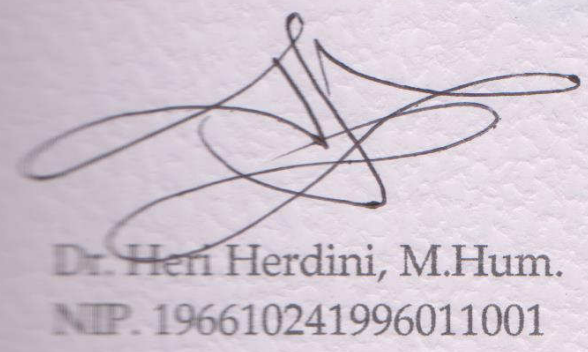

Pembimbing 2

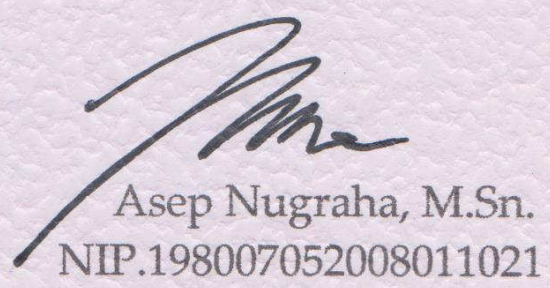

Mengetahui,

Ketua Jurusan/ Program Studi Seni Karawitan

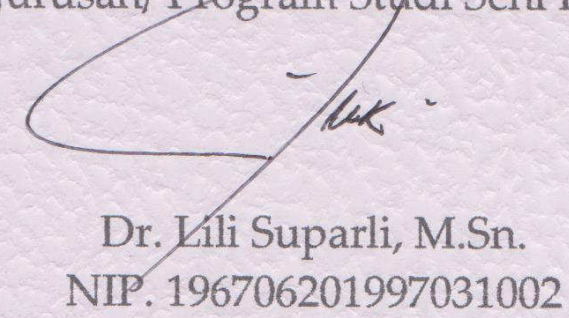




\title{
PENGESAHAN
}

\author{
SKRIPSI \\ KARYA SENI
}

KACAPI INDUNG PANGANTEUR DINA CARITA DUA TEUSAR

\author{
Oleh \\ AGUS DIANTARA \\ 15123005
}

Telah dipertahankan di depan dewan penguji melalui sidang tugas akhir Pada 26, Juni 2019

Susunan Dewan Penguji

Ketua Dewan Penguji

Renguji Utama

Anggota

Anggota

Rembimbing/anggota
: Dr. Lili Suparli, M.Sn.

: Dr. M. Yusuf Wiradiredja, M.Hum.

: Mustika Iman Zakaria S, M.Sn

: Caca Sopandi, S.Sen., M.Sn.

: Asep Nugraha, M.Sn

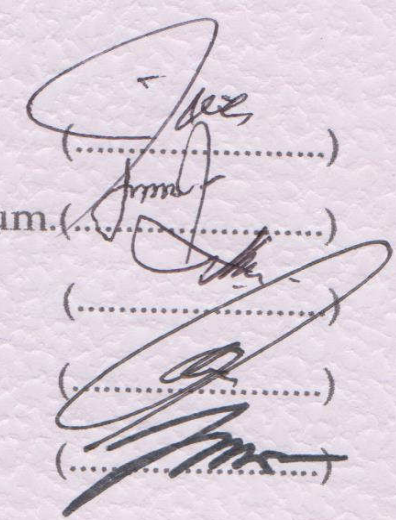

Pertanggungjawaban tertulis karya seni/Karya tulis ini telah disahkan sebagai salah satu persyaratan untuk memperoleh gelar Sarjana Seni Fakultas Seni Pertunjukan, Institut Seni Budaya Indonesia (ISBI) Bandung

Mlengetahui, Ketua Jurusan, 7 -egram Studi Seni Karawitan
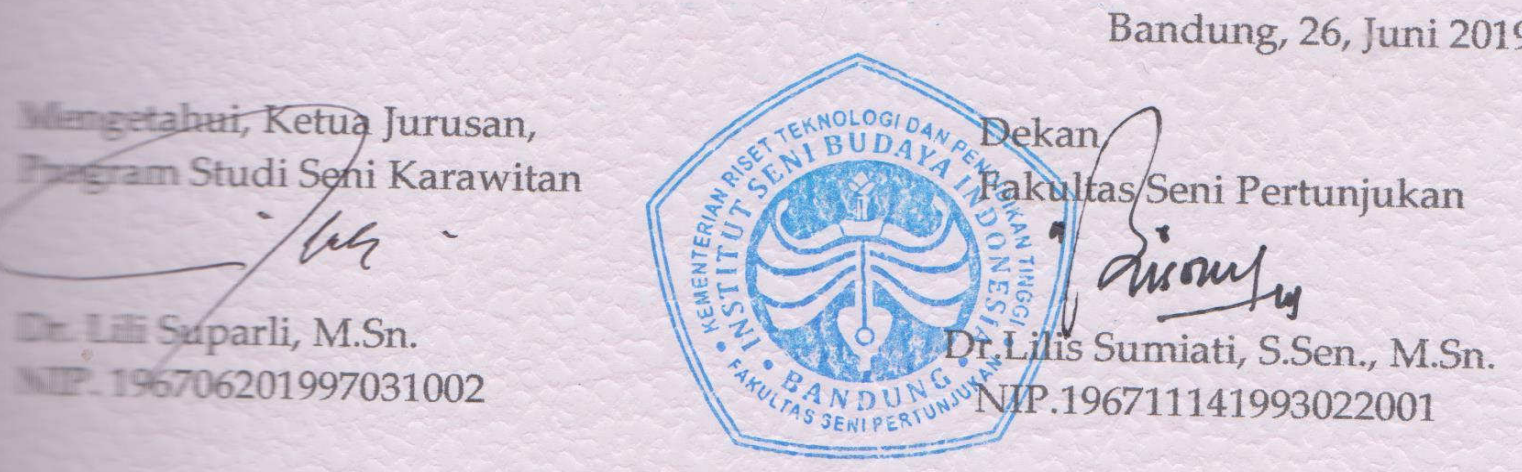


\section{PERNYATAAN}

Saya menyatakan bahwa SKRIPSI KARYA SENI dengan judul: "KACAPI INDUNG PANGANTEUR DINA CARITA DUA TEU SARASA" beserta seluruh isinya adalah benar-benar karya saya sendiri. Saya tidak melakukan penjiplakan atau pengutipan atau tindakan plagiat melalui cara-cara yang tidak sesuai dengan etika keilmuan akademik. Saya bertanggungjawab dengan keaslian karya ini dan siap menanggung resiko atau sanksi apabila dikemudian hari ditemukan hal-hal yang tidak sesuai dengan pernyataan ini.

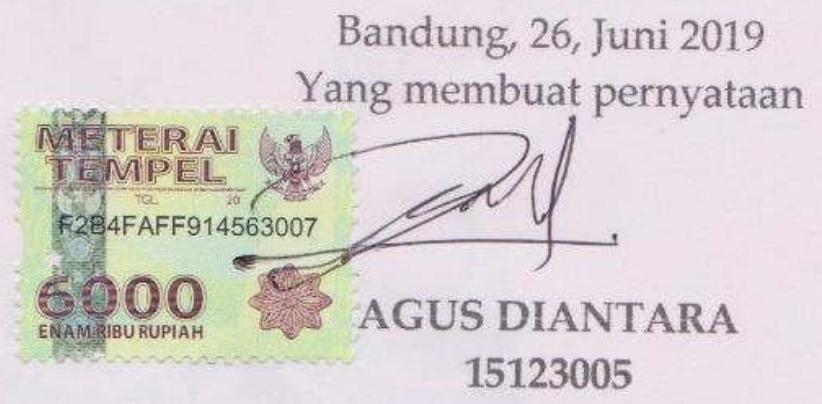




\begin{abstract}
ABSTRAK
Kacapi Indung Panganteur Dina Carita Dua Teu Sarasa merupakan judul skripsi penyajian kacapi Tembang Sunda Cianjuran dalam bentuk Gending Karasmen. Bentuk pertunjukan tembang sunda cianjuran merupakan penyajian musik yang terdiri atas vokal dan instrumen dalam membawakan repertoar lagulagunya (Wiradiredja, 2014:128). Penyajian semacam itu mendudukkan tembang sunda cianjuran diklasifikasikan sebagai bentuk sekar-gending. Sekar dihasilkan melalui suara manusia yang disajikan oleh vocalis atau disebut juru mamaos (penembang), sedangkan gending dihasilkan bunyi tetabuhan instrumen alat musik.

Gending Karasemen Tembang Sunda Cianjuran adalah sebuah seni pertunjukan yang terbentuk dari hasil perpaduan beberapa unsur-unsur seni yang dibingkai dalam sebuah lakon carita yang dihantarkan oleh musik karawitan sunda, khususunya waditra yang biasa dipakai dalam penyajian Tembang Sunda Cianjuran diantaranya: kacapi indung, suling, rincik, kenit, rebab dan biola. Tema dan isi cerita gending Karesmen biasanya diambil dari cerita pantun Sunda, cerita legenda, atau sempalan kejadian yang ada di masyarakat Tatar Sunda.

Tugas Akhir Karya Seni ini penyaji menggunakan teori kreativitas menurut Utami Munandar. Bahwa kreativitas adalah hasil interaksi antara individu dan lingkungannya, kemampuan untuk membuat kombinasi baru, berdasarkan data, informasi, atau unsur-unsur yang sudah ada atau dikenal sebelumnya, yaitu semua pengalaman dan pengetahuan yang telah diperoleh seseorang selama hidupnya baik di lingkungan sekolah, keluarga, maupun lingkungan masyarakat. Dalam konteks Tembang Sunda Cianjuran adanya kreativitas dari masa ke masa masih bisa dirasakan sampai sekarang.

Metode yang penyaji gunakan untuk merealisasikan sebuah karya ke dalam pertunjukan Tugas Akhir ini meliputi: Pemilihan lagu berdasarkan dengan tema yang diusung penyaji untuk memenuhi kebutuhan jalan cerita, Lagu tersebut disusun berdasarkan tema sajian.
\end{abstract}

Kata Kunci: Kacapi, Gending Karasmen, Tembang Sunda Cianjuran 


\section{KATA PENGANTAR}

Puji dan syukur penyaji panjatkan ke hadirat Allah SWT yang telah melimpahkan rahmat serta ridha-Nya sehingga penyaji dapat menyelesaikan skripsi Tugas Akhir ini. Skripsi ini diajukan untuk memenuhi persyaratan akademis dalam menyelesaikan program studi Strata 1 (S-1) di Institut Seni Budaya Indonesia (ISBI) Bandung. Selain itu, skripsi ini sebagai pendokumentasian karya seni dalam bentuk tulisan, manfaat lainnya mahasiswa diharapkan terbiasa dengan menuliskan sebuah sajian yang akan disajikan.

Atas terselesaikannya skripsi tugas akhir ini, penyaji mengucapkan banyak terimakasih kepada seluruh pihak yang telah membantu dalam proses pengerjaan skripsi ini. Ucapan khusus penulis ucapkan terimakasih kepada:

1. Dr. Hj. Een Herdiani, S.Sen., M.Hum. selaku Rektor ISBI Bandung.

2. Dr. Lili Suparli, M.Sn, selaku ketua Jurusan Prodi Seni Karawitan.

3. Dr. Heri Herdini, M.Hum. selaku pembimbing I.

4. Asep Nugraha, M.Sn. selaku pembimbing II.

5. Komarudin, S.Kar., M.M. selaku Wali Dosen.

6. Bapak ibu dosen pengajar Prodi Seni Karawitan ISBI Bandung. 
7. Kedua orang tua tercinta.

8. Kaka tercinta Rohmansyah.

9. Adik tercinta Lilis Krisnawati

10. Yusi Desiana

11. Teman dan sahabat

12. Samsi al-haris, selaku narasumber penyadapan.

13. Para pendukung sajian.

14. Seluruh mahasiswa Prodi Seni Karawitan angkatan 2015 ISBI Bandung.

15. Seluruh mahasiswa Prodi Seni Karawitan.

Proposal ini diharapkan dapat menerangkan masksud dari karya seni penyaji yang akan disajikan saat tugas akhir. Hal ini juga untuk memudahkan mahasiswa untuk mengingat karya seni. Tulisan juga memberikan batasan bagi penyaji agar tidak ada unsur yang berlebihan.

Bandung, 26 Juni 2019

AGUS DIANTARA 


\section{DAFTAR ISI}

HALAMAN JUDUL

HALAMAN PERSETUJUAN

HALAMAN PENGESAHAN

HALAMAN PERNYATAAN

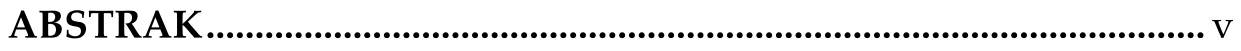

KATA PENGANTAR .......................................................................... vi

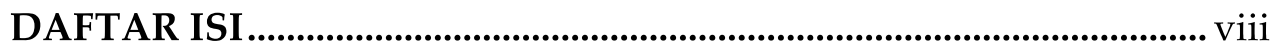

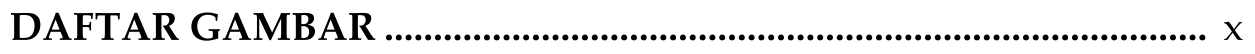

DAFTAR LAMPIRAN.................................................................... $\mathrm{xi}$

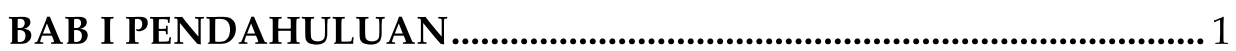

1.1 Latar Belakang Gagasan............................................................. 1

1.2 Rumusan Gagasan .................................................................. 7

1.3 Tujuan dan Manfaat.................................................................... 8

1.4 Tinjauan Sumber Penyajian ................................................... 8

1.4.1 Sumber Audio.................................................................... 9

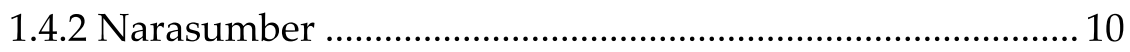

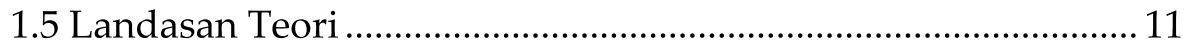

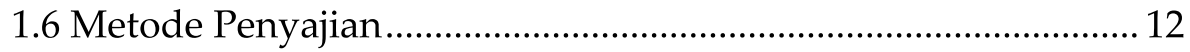

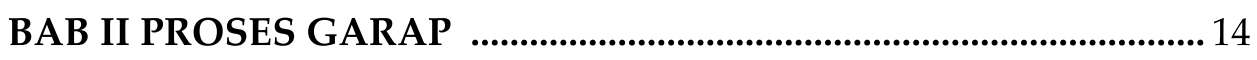

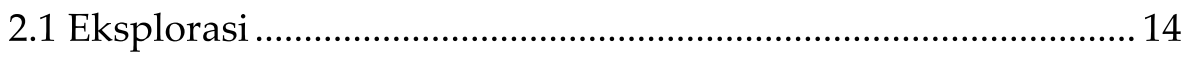

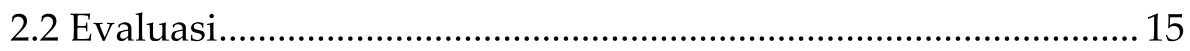

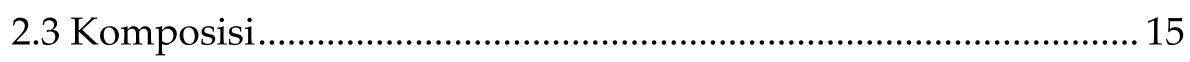

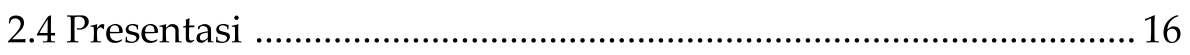

BAB III DESKRIPSI DAN PEMBAHASAN KARYA SENI ................ 18

3.1 Ikhtisar Karya Seni .................................................................. 18

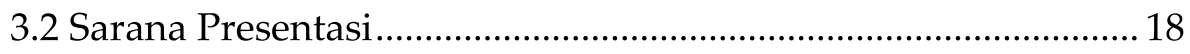

3.2.1 Lokasi Dan Bentuk Panggung .............................................. 19

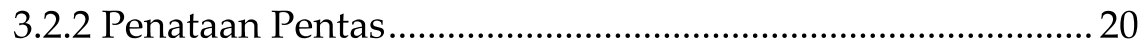

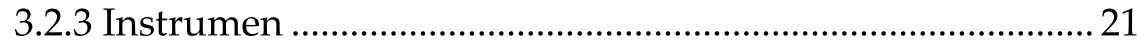

3.2.4 Desain Kostum .................................................................... 24

3.2.5 Pendukung Garapan......................................................... 26

3.3. Deskripsi Penyajian ................................................................. 27 


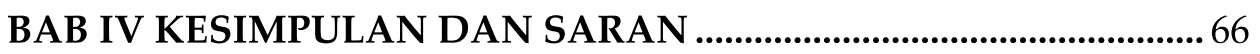

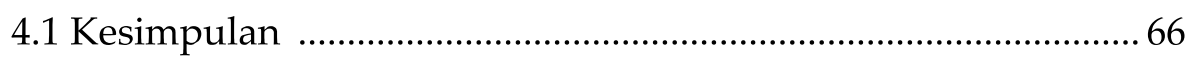

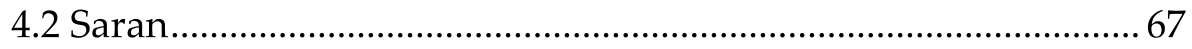

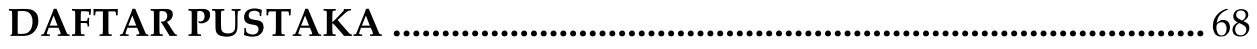

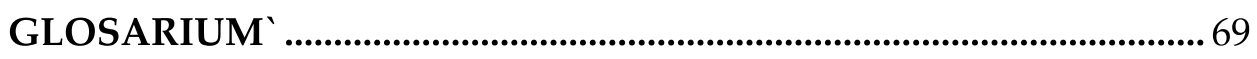

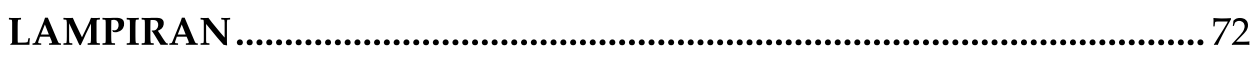




\section{DAFTAR GAMBAR}

Gambar 1. Lokasi Panggung .................................................................... 19

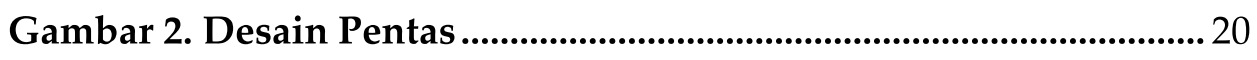

Gambar 3. Kacapi Indung......................................................................... 22

Gambar 4. Kacapi Rincik ......................................................................... 24

Gambar 5. Desain Kostum.................................................................... 25

Gambar 6. Dokumentasi hari H ......................................................... 77

Gambar 7 Adegan saat salaki akan bertemu Risma .............................. 77

Gambar 8. Adegan salaki bersama pamajikan ..................................... 78

Gambar 9. Adegan salaki akan meninggalkan pamajikan ................... 78

Gambar 10. Adegan salaki saat berada di kantor bersama Risma ..... 79

Gambar 11. Adegan salaki akan meminang Risma ........................... 79

Gambar 12. Penyaji bersama pendukung sajian. ................................... 80

Gambar 13. Dokumentasi penyaji dengan pembimbing ..................... 80

Gambar 14. Dokumentasi penyaji bersama kaka kandung.................. 81 


\section{DAFTAR LAMPIRAN}

Lampiran 1. Naskah Dua Teu Sarasa ..................................................... 72

Lampiran 2. Dokumentasi Karya Seni ................................................ 77

Lampiran 3. Form Kegiatan Bimbingan TA ....................................... 82

Lampiran 4. Curriculum Vitae ................................................................ 87 


\section{BAB I}

\section{PENDAHULUAN}

\subsection{Latar Belakang Penyajian}

Tembang sunda cianjuran merupakan musik rural $^{1}$ sebagai sumber, dengan puisi/verse melodi ritmis dan etnis yang diwarnai nilai-nilai tradisi, berdasarkan adlibitum² lokasi dan kronologi (Soepandi, 1983:16). Perjalanan tembang sunda cianjuran dalam percaturan karawitan Sunda melewati perjalanan ruang dan waktu yang panjang. Ada pergantian istilah yang melekat pada kesenian ini, dimulai tembang pajajaran dan mamaos. Fenomena ini ditulis Jheinita Ayu Pratami dalam skripsi sebagai berikut:

Pada mulanya tembang sunda cianjuran dikenal dengan sebutan tembang pajajaran yang dikemukakan oleh R.A.A. Kusumaningrat ketika waktu itu sedang menjabat sebagai bupati Cianjur ke-8 (1834-1863). Akan tetapi istilah tembang pajajaran bertahan tidak cukup lama karena diganti dengan sebutan mamaos oleh R.A.A. Prawiradiredja II, yang menjadi bupati cianjur ke 9 (1862-1910) (Jheinita Ayu Pratami, 2018:1).

Istilah mamaos tidak bertahan lama, karena pada tahun 1932 M.A Salmun memberi mandat kepada R. Emung Purawawinata yang pada waktu itu merupakan kepala siaran radio NIROM (Nederlands-Indische

\footnotetext{
${ }^{1}$ Rural merupakan kata sifat yanh memiliki arti pedalaman seperti di Desa.

${ }^{2}$ Adlibitum menurut KBBI artinya kebebasan/sesuai dengan cita rasa
} 
Radio Omroep Maatschappij), untuk lagu-lagu daerah di Bandung. Tugas tersebut adalah penyusunan nama atau istilah pada berbagai jenis kesenian Sunda agar tidak terkesan tumpang tindih. Semenjak itu lahir istilah tembang sunda cianjuran untuk mengganti istilah mamaos.

Bentuk pertunjukan tembang sunda cianjuran merupakan penyajian musik yang terdiri atas vokal dan instrumen dalam membawakan repertoar lagu-lagunya (Wiradiredja, 2014:128). Penyajian semacam itu mendudukkan tembang sunda cianjuran diklasifikasikan sebagai bentuk sekar-gending. Sekar dihasilkan melalui suara manusia yang disajikan oleh vocalis atau disebut juru mamaos (penembang), sedangkan gending dihasilkan bunyi tetabuhan instrumen alat musik. Instrumen alat musik (Sunda: waditra) yang digunakan dalam pertunjukan tembang sunda cianjuran di antaranya kacapi indung, kacapi rincik, kacapi kenit, suling, dan rebab. Terkadang digunakan pula biola atau disebut piul ${ }^{3}$ dalam penyajiannya.

Dalam sajian pertunjukan kacapi indung dalam tembang sunda cianjuran mempunyai peran dan fungsi penting. Kacapi indung dikatakan sebagai unsur pokok dalam kesenian ini. Pernyataan tersebut sesuai dengan yang dikemukakan oleh Heri Herdini (2003:15) sebagai berikut

\footnotetext{
${ }^{3}$ Piul merupakan istilah lain dari alat musik biola dalam bahasa Sunda
} 
"peranan kacapi indung sangat besar, berfungsi sebagai penuntun lagu, sebagai aba-aba masuknya lagu, dan pengukur irama lagu." Bahkan kacapi indung juga bisa disebut sebagai nyawa atau pusat dalam sajian tembang sunda cianjuran karena dalam sajiannya kerap kali melantunkan bunyibunyian yang dihasilkan dari tabuhan atau pirigan kacapi indung yang mendominasi sepanjang jalannya sajian. Berbeda dengan juru mamaos dan waditra-waditra pengiring lainnya, yaitu ada waktunya diam atau berhenti ketika sajian sedang berlangsung.

Pada dasarnya pemain kacapi indung dituntut untuk memberi kenikmatan, tuntunan, dan kenyamanan bagi juru tembang dan pamirig lainnya yang memainkan suling, rincik, dan rebab/biola. Dengan demikian bagi pemain kacapi indung diharuskan untuk memahami dan menguasai unsur-unsur musikal seperti ritmik, tempo, harmonisasi, dinamika, dan lain-lain, sebagai pondasi keterampilan (skill) untuk memenuhi tuntutan memberi kenikmatan, kenyamanan dan tuntunan bagi penembang dan pamirig.

Tembang sunda cianjuran juga mempunyai bentuk penyajian yang sangat beragam, di antaranya bisa disajikan dengan sajian konvesional, setra karesmen dan gending karesmen. Penyajian dengan bentuk konvesional adalah penyajian tembang sunda cianjuran yang di dalamnya terdapat 
struktur pertunjukan yang baku seperti susunan wanda dan susunan penggunaan tangga nada (laras). Penyajian setra karesmen yaitu penyajian tembang sunda cianjuran yang mengetengahkan lakon atau naskah tanpa dibuat adegan seperti pertunjukan teater, mirip seperti penyajian wawacan (Su'eb, 1997:2). Hal itu berbeda dengan gending karesmen yang disajikan dalam tembang sunda cianjuran. Di dalamnya terdapat gerak penembang memainkan peran suatu tokoh melalui peragaan gerak dan lantunan lagulagu tembang sunda cianjuran.

Namun, dari tiga bentuk penyajian tembang sunda cianjuran di atas, penyaji tertarik untuk menyajikan gending karesmen dalam Tembang Sunda Cianjuran. Gending karesmen adalah sebuah seni pertunjukan yang terbentuk dari hasil perpaduan beberapa unsur-unsur seni yang dibingkai dalam sebuah lakon carita yang dihantarkan oleh musik karawitan Sunda. Gending karasmen yaitu berasal dari kata "Gending" yang berarti “lalaguan", sedangkan istilah "karesmen" menurut Iim dalam Caca Soepandi menyatakan Karesian/Kreatifitas (wawancara)..

Ketika penyajian tembang sunda cianjuran dibawakan dalam bentuk gending karesmen tentu ada kelebihan dan kekurangan dalam penyajiannya. Berdasarkan data empiris yang penyaji temukan dari sisi kelebihannya adalah bisa menyampaikan makna atau isi pertunjukan 
dengan cara menambahkan komunikasi non verbal. Hal ini sangat membantu bagi apresiator yang kurang memahami kata-kata yang tidak biasa didengar dalam kegiatan sehari-hari yang diucapkan melalui juru tembang dengan cara dinyanyikan. Sedangkan dari sisi kelemahannya adalah resonasi dan vibrasi nasal, selain kurang bagus kedengarannya hal ini bisa mengurangi volume suara dan bernyanyi kurang lepas sehingga terjadi kesalahan-kesalahan artikulasi dan phonasi.

Kedudukan kacapi indung dalam gending karesmen tembang sunda cianjuran bisa dikatakan sangatlah penting atau vital dalam pertunjukan. Kacapi indung juga mempunyai fungsi dalam pertunjukan ini, seperti pengiring lagu, iringan gerak pemain dan pengiring musik ilustrasi.

Berkaitan dengan waditra kacapi yang menjadi pemimpin ketika berlangsungnya pertunjukan, hal ini merupakan sebuah tantangan tersendiri bagi penyaji karena harus membawakan sajian gending karesmen yang pada sebelumnya tidak dipelajari secara khusus dalam perkuliahan. Namun setelah mendapatkan mata kuliah kreativitas karawitan dan aransemen penyaji tertarik untuk menampilkan sebuah pertunjukan pada Tugas Akhir (TA) dengan garap nonkonvensional yang medianya adalah kacapi indung dalam kesenian tembang sunda cianjuran dengan mengangkat 
fenomena sosial poligami yang akan diangkat menjadi sebuah tema cerita dalam pertunjukan nanti.

Oleh karena itu dalam penyajiannya, penyaji memilih judul “Kacapi Indung Panganteur Dina Carita Dua Teu Sarasa". Kacapi indung adalah alat musik, instrumen atau waditra yang digunakan sebagai pengiring dalam tembang sunda cianjuran. Panganteur dalam kamus bahasa Sunda (Budi Rahayu Tsamyah) yaitu "pengantar". Dina dalam kamus bahasa sunda (Budi Rahayu Tsamyah) artinya "pada atau dalam". Carita dalam kamus bahasa Sunda (Budi Rahayu Tsamyah) artinya "cerita". Dua dalam wikipedia yang artinya "angka, sistem bilangan". Teu dalam kamus bahasa Sunda (Budi Rahayu Tsamyah) yang artinya "tak, enggak, tidak". Sarasa dalam kamus Sunda (Budi Rahayu Tsamyah) artinya "satu rasa, sependapat (pertimbangan) mengenai baik atau buruk, salah atau benar". Jika proposisi istilah itu digabungkan maka arti dari "kacapi indung panganteur dina carita dua teu sarasa" adalah instrumen kacapi sebagai pengatar pada carita atau naskah dua insan manusia yang tidak lagi satu rasa atau sependapat dalam menjalankan kehidupan rumah tangga bersama.

Dalam sajian Tugas Akhir ini, penyaji juga akan bergabung dengan beberapa penyaji lainnya yang mengambil Praktik Keahlian (PK) vokal 
dan suling yang merupakan satu rumpun tembang sunda cianjuran. Penggabungan dimungkinkan karena memiliki satu visi dan misi yang sama dalam menggarap sajian tema ini. Oleh karena itu kami memutuskan untuk menggabungkan dalam sajian Tugas Akhir (TA) ini. Konsekuensi dari itu semua adalah persepsi untuk menyatukan kesamaan pemilihan lagu, konsep garap, desain panggung dan unsur-unsur pendukung lain yang bersangkutan dengan sajian Tugas Akhir.

\subsection{Rumusan Gagasan}

Kacapi indung panganteur dina carita dua teu sarasa merupakan suatu sajian kacapi indung dalam tembang sunda cianjuran yang dibawakan oleh penyaji dalam ujian Tugas Akhir karya seni penyajian program S-I Prodi Karawitan ISBI Bandung tahun 2019. Berdasarkan latar belakang yang sebelumnya telah dijelaskan, dalam pertunjukannya, penyaji akan menyajikan tembang sunda cianjuran yang berbeda dengan pertunjukan tembang sunda cianjuran pada biasanya. Dengan membawakan sebuah cerita atau naskah yang diangkat melalui fenomena sosial poligami yang dirasa sangat menarik untuk dijadikan sebuah pertunjukan yang jarang dibawakan dalam pertunjukan TA di ISBI Bandung. 


\subsection{Tujuan dan Manfaat}

\subsubsection{Tujuan}

Pembawaan kacapi indung dalam tembang sunda cianjuran ini bertujuan untuk:

a. Mengaplikasikan materi yang telah diperoleh penyaji selama perkuliahan.

b. Mengembangkan penyajian kacapi indung dalam tembang sunda cianjuran dalam konsep yang baru.

\subsubsection{Manfaat}

a. Menjadi tolak ukur bagi penyaji dalam penyelesaian studi dan pencapaian kompetensi keahlian pada perkuliahan di Prodi Karawitan ISBI Bandung;

b. Dapat menjadi rujukan mengenai sajian tembang sunda cianjuran dalam konsep yang baru.

\subsection{Tinjauan Sumber Penyajian}

Ada beberapa sumber yang digunakan penyaji untuk menambah referensi dalam penyajian ini seperti sumber tulisan dari buku, skripsi, artikel, dan lain-lain, yakni sebagai berikut: 


\subsubsection{Sumber Audio}

Dalam penyajian ini, menggunakan sumber rekaman yang digunakan sebagai upaya menambah pembendaharaan materi lagu Tembang Sunda Cianjuran. Adapun sumber rekaman yang digunakan adalah sebagai berikut:

1. Dangdanggula Degung, Mp3 dengan juru kacapi indung, Dede Suparman, dan penembang Ida Widawati. Rekaman Mp3 tersebut memberikan gambaran mengenai gaya tabuhan kacapi indung dalam pola tabuhan pasieupan, yang dirujuk penyaji terutama pola tabuhan merean yang khas.

2. Rahwana gandrung, Video youtube dengan juru kacapi Asep Nugraha, penembang Yus Wiradiredja dan Rosyanti. Video dari audio visual ini memberikan gambaran mengenai pola pirigan lagu panambih dalam iringan lagu Rahwana Gandrung yang relatif baru di dunia tembang sunda cianjuran. Dengan kata lain, penyaji mengimitasi tabuhannya;

3. Kaleon, Mp3 yang mengetengahkan juru kacapi indung, Heri Herdini dengan panembang Rosyanti. Rekaman ini sangat unik di mana kacapi rincik difungsikan dalam iringan lagu Kaleon. Hal itu yang diadopsi oleh penyaji ke dalam pertunjukan TA. 
4. Pamuradan, Mp3., dengan juru kacapi indung Rukruk Rukmana dan penembang Euis Komariah. Penyaji mengadopsi gaya tabuhan Rukmana dalam iringan lagu tersebut untuk diaplikasikan dalam pertunjukan TA.

5. Kapeurih, Mp3, dengan juru kacapi indung Rukruk Rukmana dan penembang Ida Widawati yang diadopsi penyaji untuk diterapkan dalam pertunjukan.

\subsubsection{Narasumber}

Dalam menambah pembendaharaan materi ujian, di luar perkuliahan penyaji berguru kepada seniman dan dosen lainnya sebagai salah satu upaya dalam mempersiapkan ujian Tugas Akhir. Adapun Narasumber tersebut adalah:

a. Asep Nugraha

Dari seniman tersebut penyaji dapat menguasai beberapa pola tabuhan kacapi indung dalam lagu-lagu laras Pelog/degung dan madenda/sorog; seperti Balenderan, Udan Mas, Asmarandana Degung, dan Lokatmala. 
b. Asep Wahyudin

Dari seniman tersebut penyaji dapat mengetahui perbedaan antara wanda papantunan, rarancagan dan dedegungan. Tidak hanya itu beliau mengajarkan pola tabuh kacapi rincik dalam lagu-lagu panambih pada Tembang Sunda Cianjuran.

c. Samsi Al-haris

Dari seniman tersebut penyaji dapat mengetahui teknik variasi dalam memainkan kacapi indung yang ada pada wanda jejemplangan.

\subsection{Landasan Teori Karya Seni}

Dalam Tugas Akhir Karya Seni Penyajian dengan judul Kacapi Indung Panganteur Dina Carita Dua Teu Sarasa, penyaji menggunakan teori kreativitas menurut Utami Munandar. Bahwa kreativitas adalah hasil interaksi antara individu dan lingkungannya, kemampuan untuk membuat kombinasi baru, berdasarkan data, informasi, atau unsur-unsur yang sudah ada atau dikenal sebelumnya, yaitu semua pengalaman dan pengetahuan yang telah diperoleh seseorang selama hidupnya baik itu di lingkungan sekolah, keluarga, maupun dari lingkungan masyarakat. 
Dalam konteks Tembang Sunda Cianjuran adanya kreativitas dari masa ke masa masih bisa dirasakan sampai sekarang. Bisa kita lihat contohnya, yang pada awal kemunculannya kesenian ini hanya diiringi dengan instrumen kacapi indung dan suling saja, namun seiring perkembangan jaman, Tembang sunda cianjuran terdapat perubahan bertambahnya instrumen pengiringnya yaitu kacapi rincik, dan bahkan dikolaborasikan dengan alat musik barat yaitu piul atau biola untuk memperbarui garap musikal dalam pertunjukannya. Dalam sisi penyajiannya pun juga ada perubahan, seperti penambahan jembatan-jembatan menggunakan isntrumen kacapi, dibuatnya naskah-naskah carita, dan lain-lain.

\subsection{Metode Penyajian}

Metode penyajian adalah cara untuk menyampaikan sebuah gagasan karya seni yang akan penyaji tampilkan agar maksud dan tujuan penyaji tersampaikan dengan baik. Metode yang penyaji gunakan untuk merealisasikan sebuah karya ke dalam pertunjukan Tugas Akhir ini adalah:

a. Pemilihan lagu-lagu berdasarkan dengan tema yang di usung penyaji untuk memenuhi kebutuhan jalan cerita dalam sajian gending karasmen tembang sunda cianjuran. 
b. Lagu-lagu tersebut disusun berdasarkan tema sajian

c. Lagu yang ada dalam sajian di pirig menggunakan pola tabuh kacapi tembang sunda cianjuran pada umumnya. Hanya saja ketika perpindahan dari lagu satu ke yang lainnya menggunakan jembatan atau di medley-kan.

d. Mengubah rumpaka/lirik lagu-lagu yang dibawakan. lirik lagu disesuaikan dengan tematik yaitu tentang seorang suami yang mencintai dua orang wanita.

e. Membuat artistik dan setting panggung yang mendukung sajian agar sesuai dengan tematik. 


\section{BAB II}

\section{PROSES GARAP}

Dalam penyajian karya seni, proses sangatlah penting dilakukan karena menentukan nilai akhir dan kualitas dari karya seni yang akan disajikan. Untuk menggambarkan hal tersebut, bahasan proses penyaji terbagi ke dalam empat bahasan:

\subsection{Eksplorasi (Pencarian)}

Eksplorasi (pencarian) merupakan aktivitas penjelajahan untuk menemukan sesuatu yang diperlukan. Dalam konteks ini adalah pencarian konten yang berkaitan dengan Tugas Akhir (TA). Oleh karena itu eksplorasi dapat diartikan sebagai aktivitas pencarian sumber-sumber yang berkaitan dengan konsep penyajian, lagu-lagu, dan teknik-teknik atau motif tabuhan yang akan dibawakan pada sajian Tugas Akhir (TA) Kacapi Indung Pangateur Dina Carita Dua Teu Sarasa.

Menentukan materi lagu tentu bukan hal yang sangat mudah. Dimulai dengan mengapresiasi audio maupun audio visual seperti video youtube yang menjadi satu sumber pencarian. Sedangkan secara verbal penyaji melakukan pencarian lagu pada saat perkuliahan dan di luar 
perkuliahan. Oleh karena itu, eksplorasi menjadi unsur yang sangat penting dalam proses pembentukan karya Tugas Akhir (TA).

\subsection{Evaluasi (Penilaian)}

Evaluasi merupakan tahap penilaian atau pensortiran materi atau bahan yaitu berupa lagu, teknik penyajian dan ragam atau pola tabuh kacapi indung dalam tembang sunda cianjuran. Dalam hal ini semua aspek yang telah dilalui dalam tahapan eksplorasi mengalami proses penilaian untuk dapat digunakan dalam penyajian Tugas Akhir ini. Penilaian di sini maksudnya adalah tidak semua lagu, tekhnik peyajian, ragam atau pola tabuh bisa di gunakan, namun harus sesuai dan cocok dengan tema yang sudah di usung oleh penyaji.

\subsection{Komposisi (Pembentukan)}

Setelah melewati tahap ekplorasi dan evaluasi masuk ke dalam tahap komposisi atau pembentukan. Proses ini merupakan kelanjutan dari proses sebelumnya yaitu ekplorasi dan evaluasi yang hasilnya diolah dari materi sebelumnya kemudian di bentuk menjadi sebuah repertoar lagu, pemnempatan jembatan-jembatan lagu dan lain sebagainya. Proses ini 
berlangsung dengan para personil pendukung garapan dan konsultasi atau masukan-masukan dari dosen pembimbing.

\subsection{Presentasi (Penyajian)}

Presentesasi (Penyajian) merupakan tahap akhir dari seluruh kegiatan yang penyaji lakukan dari mulai eksplorasi (pencarian) dan komposisi (pembentukan). Adapun struktur penyajian pada penyajian ini yaitu dimulai dengan laras pelog/degung, dengan Bubuka Banjaran kemudian ada musik ilustrasi, dilanjutkan kepada wanda panambih (Kapeurih) dengan cara dimedley-kan setelah itu ada musik ilustrasi sebagai jembatan menuju wanda papantunan (Mangu-Mangu, Kaleon, Jemplang Pamirig dan Dangdanggula Degung). Perpindahan laras dari pelog/degung ke laras mandalungan juga menggunakan musik ilustrasi yang bertujuan untuk mengiringi tokoh/pemeran dalam pergantian latar dari adegan rumah ke kantor. Lagu yang digunakan dalam laras mandalungan adalah panyalahan dengan panambih Ngumbar Asih. Kemudian perpindahan dari laras mandalungan ke laras sorog juga menggunakan musik ilutrasi, lagu dalam laras sorog itu antara lain Udan Mas dengan panambih Rahwana Gandung. Lagu yang terakhir adalah Pamuradan dan 
panambih Melang Bimbang pada laras Salendro. Lagu-lagu tersebut disesuaikan dengan kebutuhan naskah. 


\section{BAB III}

\section{DESKRIPSI DAN PEMBAHASAN KARYA SENI}

\subsection{Ikhtisar Karya Seni}

Penyajian "Kacapi Indung Panganteur Dina Carita Dua Teu Sarasa" merupakan penyajian tembang sunda cianjuran disajikan dalam bentuk Gending Karasmen. Dalam bentuk penyajian gending karasmen ada beberapa garap musikal yang dihadirkan yang tidak ada pada bentuk penyajian tembang sunda cianjuran secara konvensional. Repertoar lagu disajikan secara medley lagu ke lagu disambungkan menggunakan jembatan, tatanan gending atau struktur lagu disusun mengikuti alur cerita pada naskah. Tematik yang diusung berkaitan dengan fenomena sosial dan agama tentang poligami.

\subsection{Sarana Presentasi}

Deskripsi karya seni digambarkan dengan bahasan mengenai: (1) Lokasi Pertunjukan, (2) Desain Pentas, (3) Instrumen, (4) Kostum, dan (5) Pendukung garapan. Penjabarannya dijelaskan pada subbagian berikutnya. 


\subsubsection{Lokasi Dan Bentuk Panggung}

Pertunjukan "Kacapi Indung Panganteur Dina Carita Dua Teu Sarasa" diselenggarakan di Gedung Kesenian Sunan Ambu Institut Seni Budaya Indonesia (ISBI) Bandung di Jalan Buah Batu No 212 pada tanggal 21 juni 2019. Gedung Kesenian Sunan Ambu menjadi pilihan bagi penyaji untuk menampilkan sajian ini, karena bentuk panggungnya yang prosenium menjadikan nilai lebih tersendiri dalam menampilkan sajian ini. Para pemain berhadapan langsung dengan penonton tanpa ada yang membelakangi. Hal ini bertujuan agar dapat memaksimalkan penyampaian isi dan pesan garapan kepada seluruh apresiator.

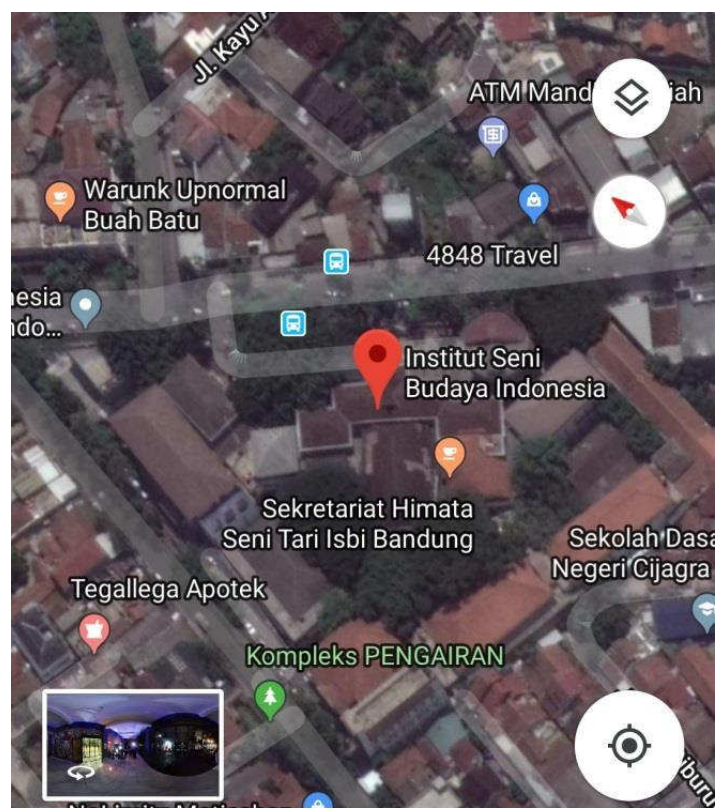

Gambar 1. Lokasi Gedung Sunan Ambu di Institut Seni Budaya Indonesia Bandung (Sumber google map) 


\subsubsection{Penataan Pentas}

Penataan pentas disusun untuk kebutuhan visual yang ikut berperan penting dalam garapan ini. Penataan pentas ini menyesuaikan dengan kebutuhan yang ada di dalam naskah yaitu terdapat 3 latar berbeda yang harus dihadirkan dalam satu panggung. Penataan pentas juga meliputi layout panggung dan layout artistik.

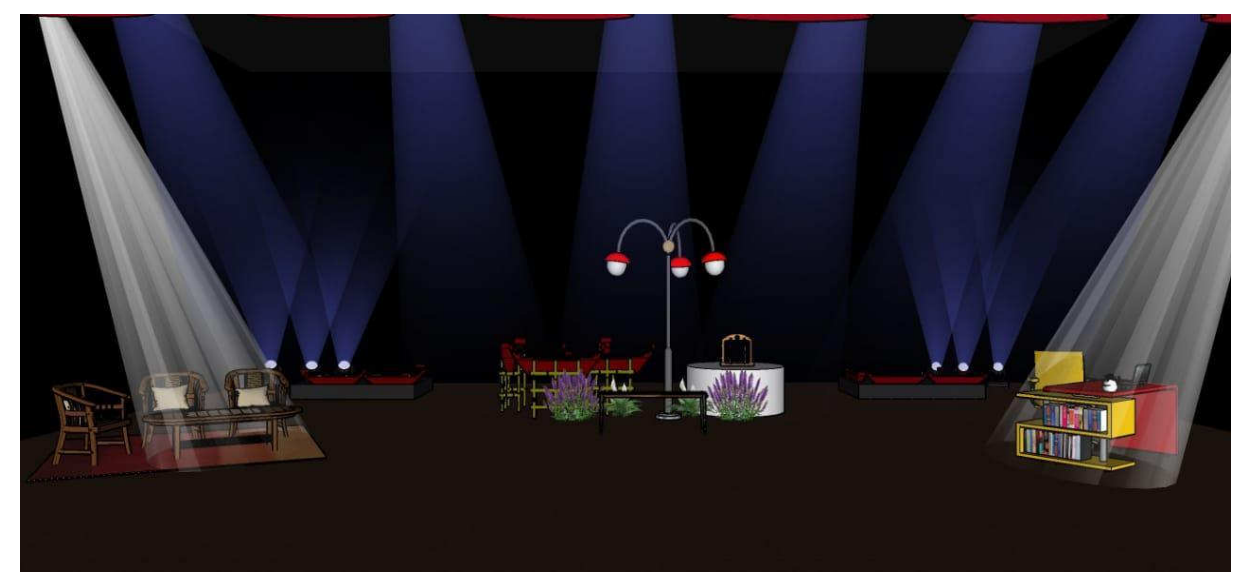

Gambar 2. Desain Pentas TA Kacapi Indung Panganteur Dina Carita Dua Teu Sarasa Keterangan:

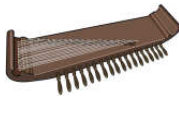

: kacapi indung
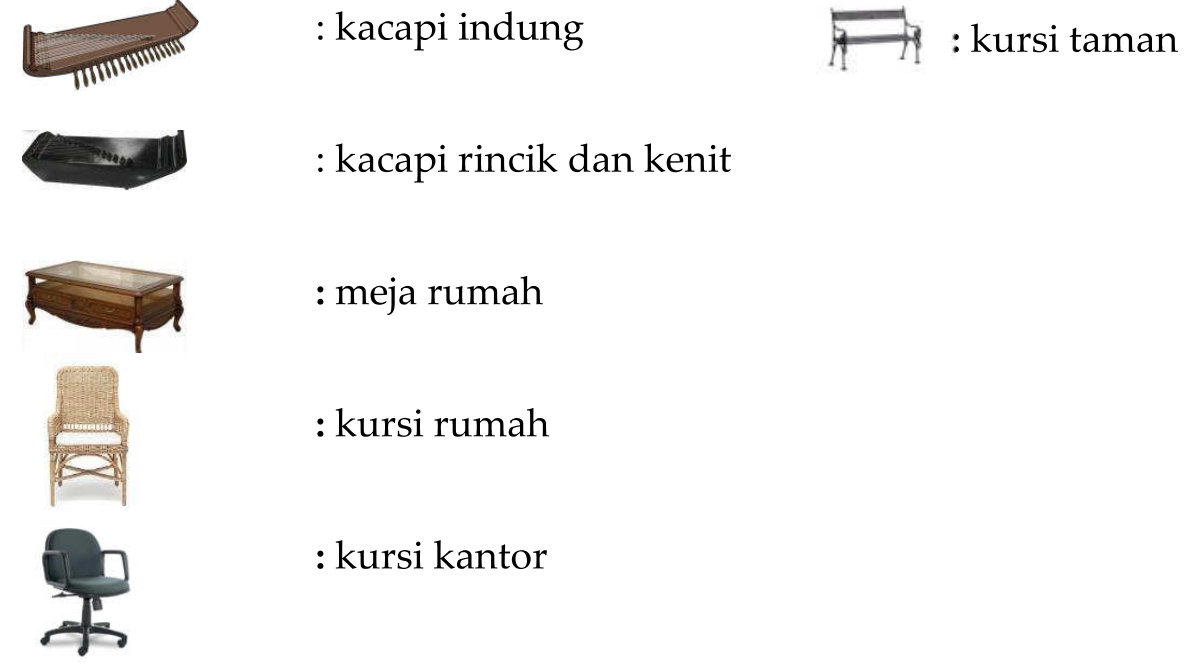

: kacapi rincik dan kenit

: meja rumah

: kursi rumah

: kursi kantor 


\subsubsection{Instrumen}

Instrument yang digunakan pada sajian "Kacapi Indung Panganteur Dina Carita Dua Teu Sarasa" menggunakan instrumen yang terdiri atas:

a. Kacapi Indung

Kacapi Indung merupakan salah satu alat musik chordophone ${ }^{4}$. Kacapi indung sendiri mempunyai nama lain yang sudah familiar di telinga masyarakat yaitu dengan sebutan kacapi parahu dan gelung, karena jika dilihat dari bentuknya memang mirip dengan bentuk perahu sedangkan di sebut gelung karena pada kedua ujungnya berbentuk gelung wayang golek (mahkota) dan sanggul pada perempuan. Bahan baku pembuatan kacapi indung terbuat dari kayu (papan) Albasiah, Kananga, dll. Sedangkan dawai atau senanrnya menggunakan kawat kuningan dimulai ukuran 0,40,9 mm yang dipakai agar saat dipetik mengeluarkan bunyi yang tidak gandeng ${ }^{5}$.

Nama-nama bagian yang ada pada kacapi indung di antaranya: papalayu yaitu papan bagian atas kacapi yang merupakan sebagai mukanya, puret yang dipasang pada bagian depan kacapi yang berfungsi sebagai alat menyetem (nyurupkeun), inang (susu) yang berbentuk kerucut

${ }^{4}$ Chordophone adalah alat musikyang sumber bunyinya dari tali senar, kawat

${ }^{5}$ Gandeng dalam kamus bahasa sunda artinya bising, berisik. 
atau limas yang juga berfungsi untuk menopang kawat dan bisa digunakan untuk soft tuning (Wiratmadja, 1996:101-102). Apabila dilihat dari fungsinya sebagai pengiring tembang sunda cianjuran, Kacapi ini lazim disebut kacapi indung. Oleh karena itu, fungsi kacapi indung sangat mendominasi dan berperan pokok dalam menuntun lagu mamaos dan panambih dalam sajian tembang sunda cianjuran.

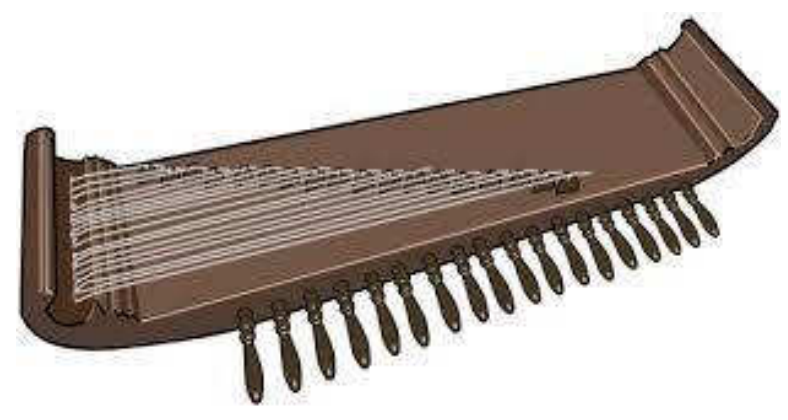

Gambar 3. kacapi indung (sumber Google)

\section{b. Kacapi Rincik}

Kecapi rincik bentuknya mirip dengan kecapi indung hanya saja ukurannya lebih kecil dari kecapi indung. Dawai yang terpasang pun memiliki jumlah yang lebih sedikit yaitu 15-16 dawai. Penggunaan dawai pada kecapi rincik menggunakan bahan yang berbeda dari kacapi indung yaitu menggunakan kawat stainless. Fungsi kacapi rincik dalam sajian tembang sunda cianjuran untuk memainkan tabuhan yang mengisi melodi 
pada lagu-lagu panambih, melodinya bervariasi mengikuti arkuh lagu pada lagu panambih tersebut .

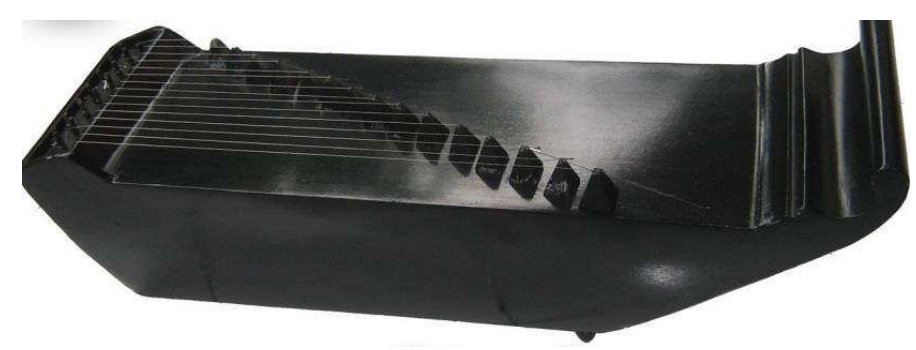

Gambar 4 kacapi rincik (Sumber Google)

c. Kacapi kenit

Kecapi kenit memiliki bentuk yang sama persis dengan kacapi rincik, seperti ukuran, jumlah dawai, dan bahan dawainya. Akan tetapi kecapi kenit mempunyai fungsi yang berbeda dari kecapi rincik. Kecapi kenit fungsinya mengisi melodi dengan ritmis berpola yang ditabuh secara repetitif hanya menabuh nada kenongan dan goongan saja pada lagu panambih.

\section{d. Suling}

Suling merupakan alat musik tiup yang terbuat dari bambu dan telah dilubangi beberapa bagian, agar dapat mengahasilkan nada yang diharapkan dan termasuk ke dalam jenis alat musik aerophone ${ }^{6}$. Biasanya, suling Sunda dibuat dari bambu teamiang/tamiang yang sudah tidak mengandung kadar air agar tahan terhadap serangan rayap. Beberapa

${ }^{6}$ Aerophone adalah alat musik yang dimainkan dengan cara ditiup 
jenis suling Sunda yang ada sangat beragam, seperti suling degung empat lubang, suling enam lubang, bahkan ada suling Sunda tujuh lubang sampai dengan sembilan lubang. Suling empat lubang sangat familiar dengan sebutan suling degung, suling ini biasanya digunakan dalam wanda dedegungan dan memiliki warna suara yang khas. Sedangkan, suling enam lubang biasa disebut dengan suling tembang. Tentu saja, suling tembang ini dominan digunakan dalam mengiringi tembang sunda cianjuran. Dan apabila dilihat dari fungsi suling dalam tembang sunda cianjuran, garap musikal melodi suling memainkan fungsi dan peranan penting, di antaranya: merean, yaitu memberikan nada awal pada frase lagu atau pada awal kalimat lagu, juga berfungsi sebagai pemberi aba-aba kepada juru mamaos untuk memulai nembang, ngabeulit adalah fungsi melodi suling yang menghasilkan susunan nada-nada penghias lagu yang dibawakan mengikuti melodi yang dibawakan oleh juru mamaos.

\subsubsection{Desain Kostum}

Desain kostum yang digunakan penyaji yaitu menggunakan Jas hitam putih. Penggunaan kostum seperti ini dalam penyajian tembang sunda cianjuran merupakan hal yang langka belum terjadi dalam penyajian 
tembang sunda cianjuran di wilayah kampus ISBI Bandung. Biasanya para pamirig dan penembang menggunakan baju takwa khas daerah sunda bagi pamirig laki-laki dan baju kebaya sunda untuk penembang perempuan. Pemilihan kostum seperti ini bertujuan untuk mensinkronkan dengan konsep yang telah diusung yaitu membawakan jalan cerita pada zaman sekarang.

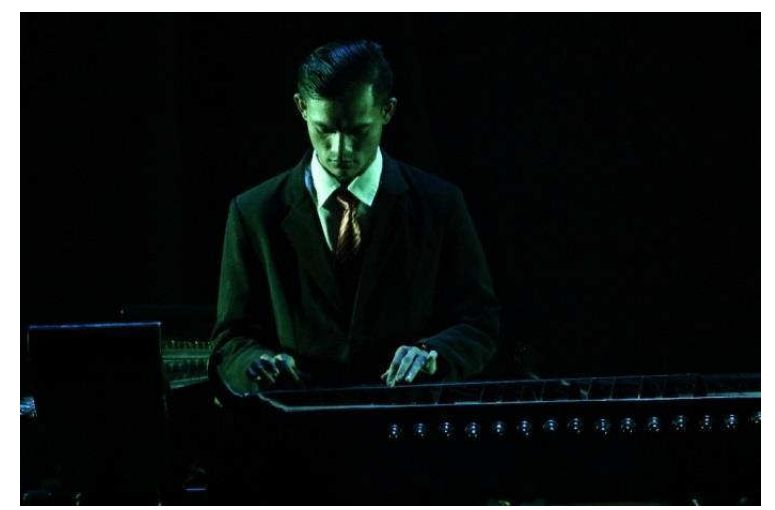

Gambar 5. Kostum yang digunakan (Dokumentasi : Herfan Rusando, 2019) 


\subsubsection{Pendukung Garapan}

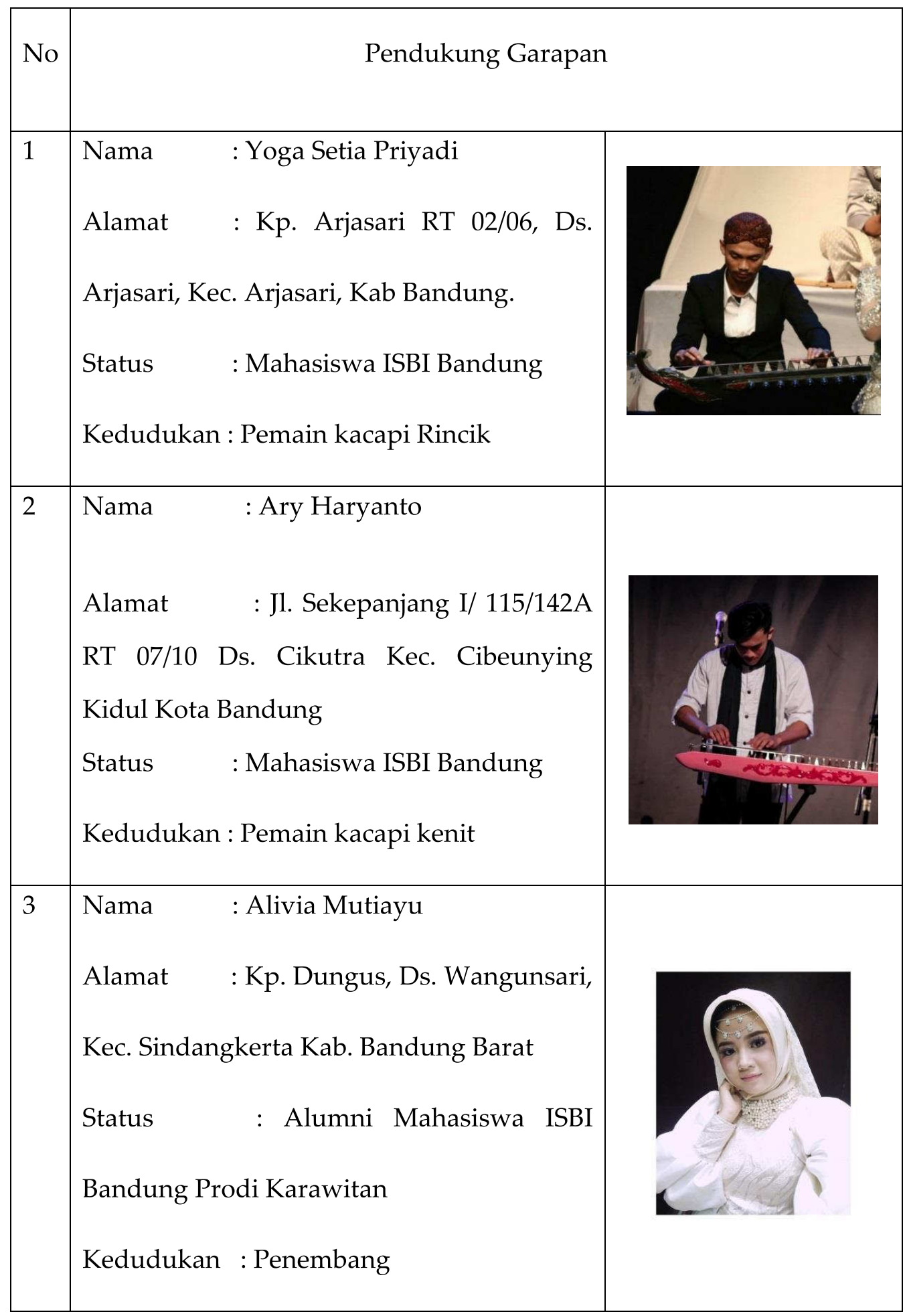




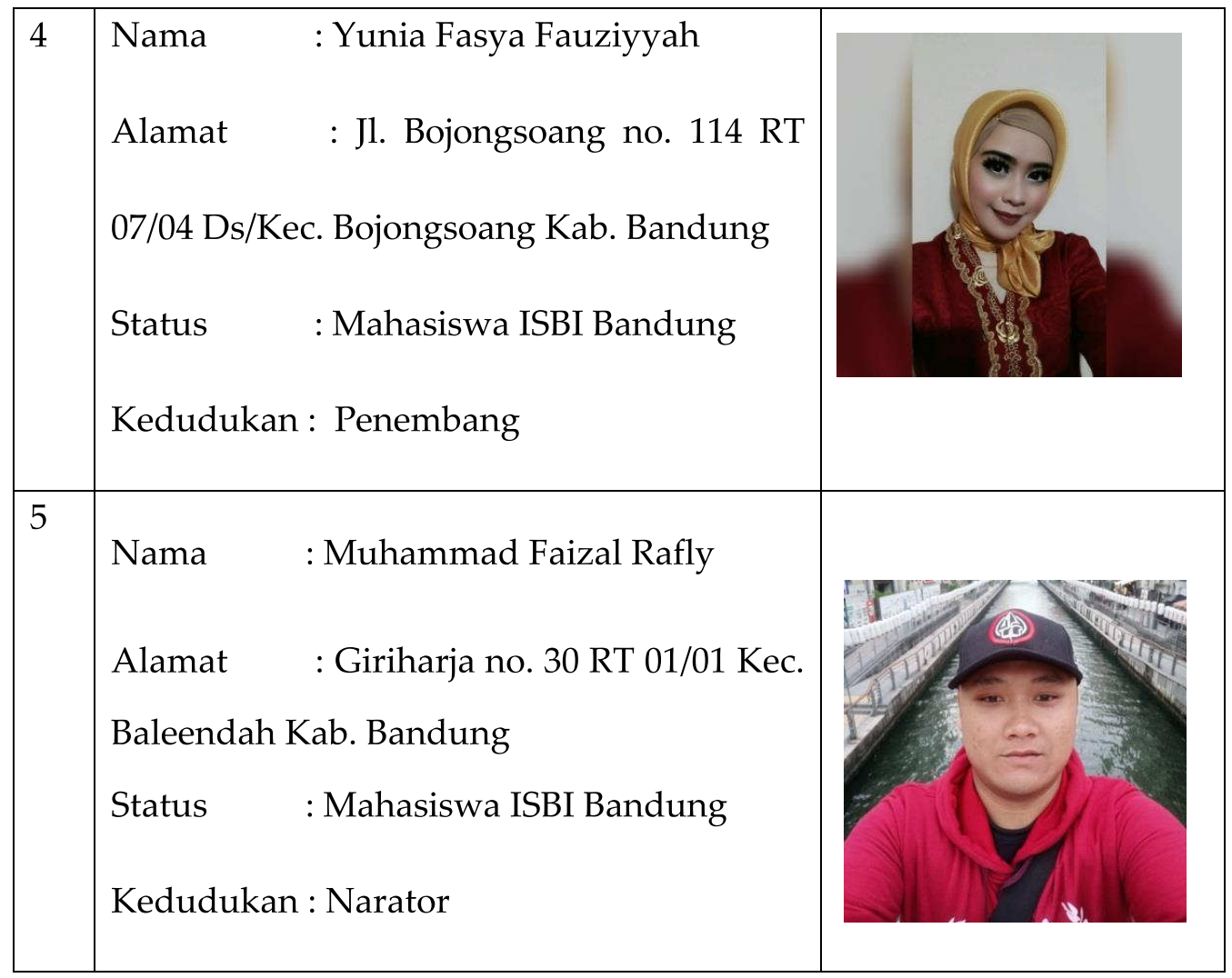

\subsection{Deskripsi Penyajian}

Dalam sajian "kacapi indung panganteur dina carita dua teu sarasa" penyaji akan membawakan beberapa lagu, repertoarnya lagunya antara lain:

\section{Banjaran}

a. Deskripsi Sajian

Banjaran merupakan sebuah lagu bubuka yang sering digunakan dalam kesenian Tembang sunda cianjuran. Lagu ini 
berbentuk gending instrumental. Laras yang digunakan dalam lagu ini bisa menggunakan Pelog $1=\mathrm{T}$ atau juga $3=\mathrm{T}$ atau mandalung, namun pada sajian ini penyaji menggunakan laras pelog $1=\mathrm{T}$

b. Notasi Lagu

Notasi yang digunakan dalam penulisan ini yaitu menggunakan notasi Serat Kanayagan yang dibuat oleh Raden Machjar Angga Koesoemadinata.

Bubuka Banjaran

$$
\begin{array}{ll}
\text { Laras } & : \text { Pelog/Degung } \\
\text { Surupan } & : 1=\mathrm{T}
\end{array}
$$

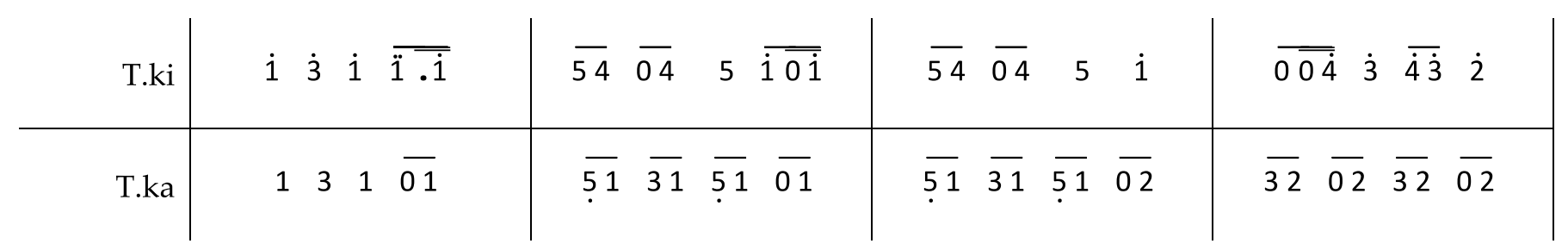

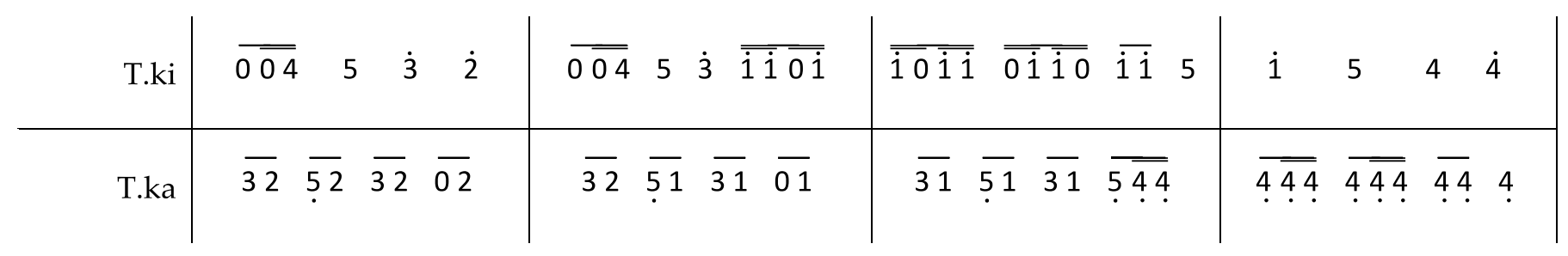




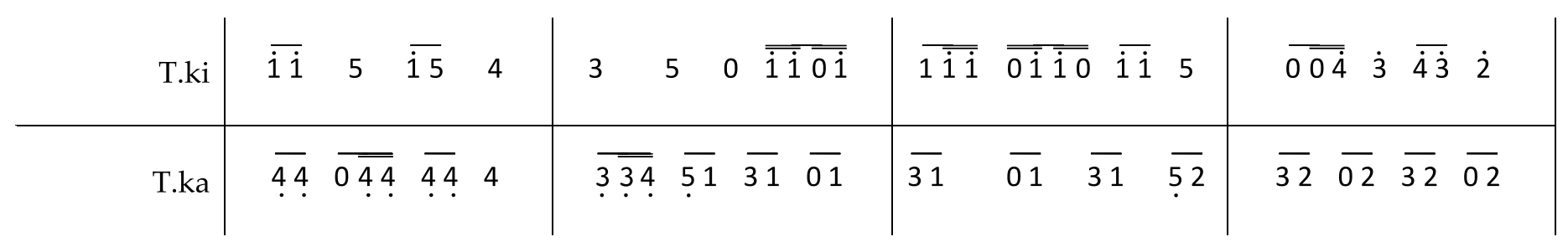

c. Jalannya Sajian

Penyajian lagu bubuka banjaran diawali dengan gending jembatan sebelum masuk ke lagu banjaran untuk memberikan kesan suasana hegar dalam pertunjukannya. Pembawaan lagu banjaran tidak dibawakan full, hanya berhenti pada goongan 4 (ti) untuk membuat jembatan instrument ke lagu selanjutnya.

2. Kapeurih

a. Deskripsi Sajian

Kapeurih merupakan sebuah lagu yang masuk kedalam golongan wanda panambih. Dalam sajian kali ini rumpaka asli diganti dengan rumpaka yang baru untuk memenuhi kebuthan naskah.

Gending jembatan

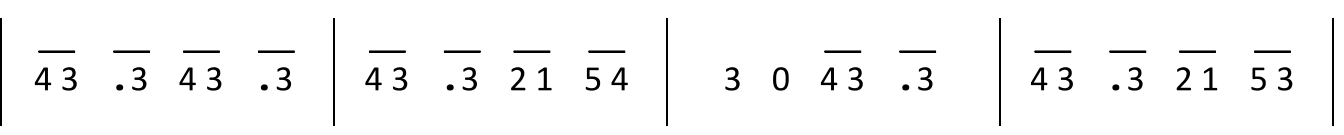


$\left|\begin{array}{llll|llll|lllll|llll}4 & 0 & \overline{43} & \overline{.3} & \overline{43} & \overline{.3} & \overline{21} & \overline{54} & \overline{32} & \overline{23} & \overline{21} & \overline{54} & \overline{34} & \overline{54} & \overline{34} & \overline{51}\end{array}\right|$

a. Deskripsi Sajian

Lagu kapeurih termasuk kedalam wanda panambih yang

berlaras degung. Rumpaka lagu ini diganti dengan yang baru untuk

menyesuaikan kebutuhan naskah.

b. Notasi Lagu

\begin{tabular}{llrl}
\multicolumn{3}{c}{ KAPEURIH } \\
Laras & $:$ Pelog & Sanggian & :Yusuf wiradiredja \\
Wanda & $:$ Panambih & Rumpaka & : Dian Hendrayana
\end{tabular}

Pola Tabuhan rofel

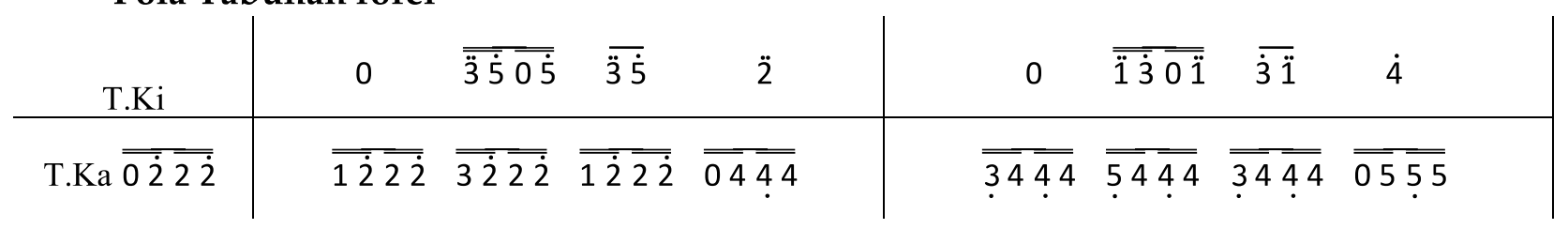

\begin{tabular}{|c|c|c|c|c|c|c|c|c|}
\hline T.Ki & 0 & $\overline{\overline{1} \dot{3} \overline{0}}$ & $\overline{\dot{3} \ddot{1}}$ & $\dot{5}$ & 0 & $\overline{\overline{3} \dot{5} \overline{05}}$ & $\overline{3 \dot{5}}$ & $\ddot{1}$ \\
\hline T.Ka & $\overline{45 \overline{55}}$ & $\overline{55}$ & $\overline{45 \overline{55}}$ & $\overline{\overline{0 i} \overline{1 i}}$ & $\overline{\overline{5 \dot{i}} \overline{1 \dot{i}}}$ & $\overline{\overline{2 i} \overline{1 i}}$ & $\overline{5 \bar{i} \overline{1 i}}$ & $\overline{\overline{02} \overline{22}}$ \\
\hline
\end{tabular}

\begin{tabular}{|c|c|c|c|c|}
\hline T.Ki & 0 & $\overline{\overline{3} \dot{5} \overline{0 \dot{5}}}$ & $\overline{3} \dot{5}$ & $\ddot{2}$ \\
\hline T.Ka & & $32 \overline{2}$ & $\overline{12 \overline{22}}$ & 0 \\
\hline
\end{tabular}


c. Jalannya Sajian

Sebelum masuk ke lagu kapeurih ada sedikit jembatan penghubung untuk menghilangkan suasana hegar yang telah sebelumnya disajikan, karena didalam lagu ini isi rumpakanya mengandung isi suasana tegang.

3. Mangu-mangu

a. Deskripsi Sajian

Mangu-mangu adalah salah satu lagu dalam tembang sunda cianjuran yang termasuk ke dalam wanda papantunan dan termasuk sekar irama merdeka atau bermetrum bebas. Struktur tabuhan kacapi indung pada lagu ini terdiri atas narangtang, daweung, gelenyu, dan iringan lagu (tabuhan kemprangan dan pasieupan). Jika dilihat dari segi rumpaka atau lirik, dalam lagu ini menggambarkan tentang kegelisahan seseorang dalam membedakan mana yang benar dan mana yang salah (dilema).

\footnotetext{
${ }^{7}$ Hegar dalam kamus bahasa Sunda artinya gembira
} 
b. Notasi Lagu

\section{MANGU-MANGU}

$\begin{array}{llll}\text { Laras } & \text { : Pelog degung } & \text { Gaya } & \text { : Heri Herdini } \\ \text { Wanda } & \text { : Papantunan } & \text { Rumpaka } & \text { :Dian Hendrayana }\end{array}$

\section{Gelenyu}

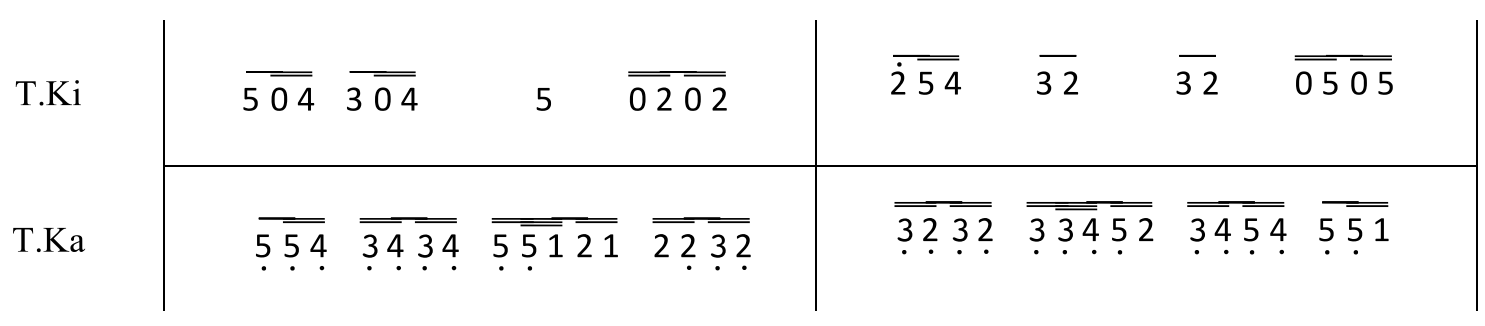

\begin{tabular}{|c|c|c|c|c|c|c|c|c|}
\hline T.Ki & $\overline{504}$ & $3 \overline{04}$ & 5 & $\dot{205}$ & $\overline{1 \overline{3 \dot{2}}}$ & $\overline{\overline{054}} \overline{02}$ & 21 & $\overline{\overline{505}}$ \\
\hline T.Ka & $\overline{\overline{51} \overline{54}}$ & $\overline{34} \overline{34}$ & $\overline{\overline{55} \overline{21}}$ & $\overline{\overline{22} \overline{25}}$ & $\overline{112} \overline{32}$ & $\overline{3032}$ & $\overline{3545}$ & $\overline{055 i}$ \\
\hline
\end{tabular}

\begin{tabular}{|c|c|c|c|c|c|c|c|}
\hline T.Ki & $\overline{\overline{5} \overline{5 \dot{5}}}$ & $\overline{\dot{3} \overline{5} \dot{5}}$ & 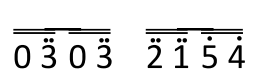 & $\overline{\dot{3} \dot{2}}$ & $\overline{\dot{3} \overline{2 \ddot{1}}}$ & $\overline{1} \ddot{1}$ & $\overline{\dot{5} \dot{5} \overline{05}}$ \\
\hline T.Ka & $\overline{\overline{5 i}} \overline{54}$ & $\overline{\overline{3 \overline{34}} \overline{54}}$ & 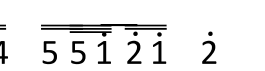 & $\overline{\overline{12} \overline{32}}$ & $\overline{3 \overline{34} \overline{52}}$ & $\overline{3 \overline{34} \overline{54}}$ & $\overline{55 \overline{5 i}}$ \\
\hline
\end{tabular}




\begin{tabular}{|c|c|c|c|c|c|c|c|c|}
\hline T.Ki & $\overline{5 \overline{5} \dot{4}}$ & $\overline{\dot{3} \overline{5} \dot{5}}$ & $\overline{\overline{0 \ddot{3}} \overline{0 \ddot{3}}}$ & $\overline{\overline{32}}$ & $\overline{\dot{3} \overline{2 \dot{3}}}$ & $\overline{\overline{03} \overline{20}}$ & $\overline{3 i}$ & $\dot{5}$ \\
\hline T.Ka & $\overline{\overline{51} \overline{54}}$ & $\overline{3 \overline{34}} \overline{54}$ & $\overline{5 \overline{5 \dot{i} \bar{i}}}$ & $\overline{3} \dot{2}$ & $3 \overline{23}$ & $51 \overline{20}$ & 321234 & 5 \\
\hline
\end{tabular}

\section{Iringan vocal}

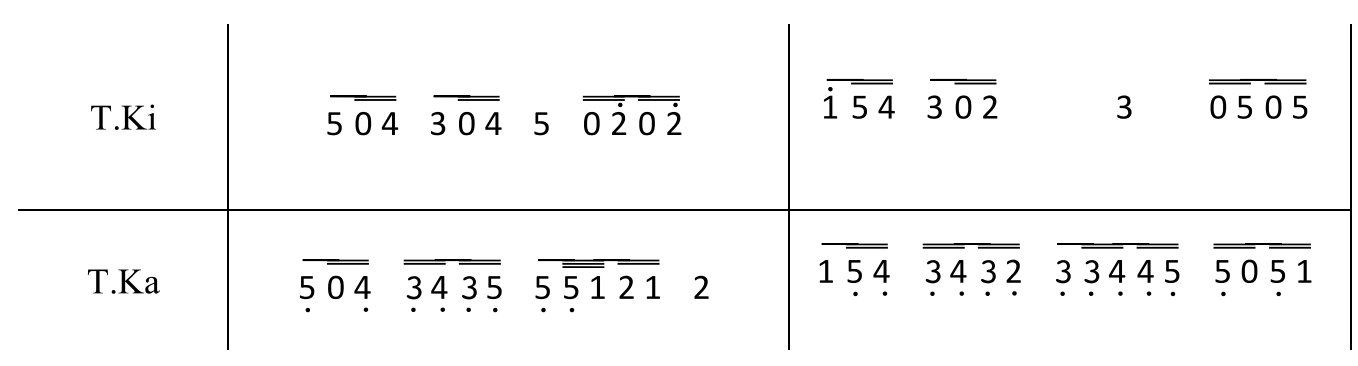

\begin{tabular}{|c|c|c|c|c|c|c|c|c|}
\hline T.Ki & $\overline{5 \overline{54}}$ & $\overline{3 \overline{04}}$ & 5 & $\overline{\overline{02} \overline{02}}$ & $\overline{i \overline{54}}$ & $\overline{302}$ & 3 & 5 \\
\hline T.Ka & $\overline{\overline{51} \overline{54}}$ & $\overline{34} \overline{35}$ & $\overline{5 \overline{5121}}$ & $=\overline{22}$ & $\overline{154}$ & 34.32 & $3 \overline{3454}$ & $5 \overline{05}$ \\
\hline
\end{tabular}

Tabuhan pasieupan

Merean $5+$ nunggu 5

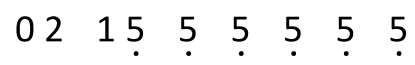

Utun inji buah ati

Golosor $5+$ Merean $2+$ Nunggu 2

$5 \quad 55 \quad 543 \quad 4 \quad 345 \quad 545 \quad 34 \quad 32$

abdi mah am pun, deu deuuhhh 
Nunggu $5+$ golosor 2

$\begin{array}{lllllll}5 & 4 & 552 & 22 & 2 & 2 & 2\end{array}$

Duh Gusti Nu Maha Heman

Merean $5+$ beulit 1

$\begin{array}{lllllll}2 & 15 & 551 & 2 & 2 & 2 & 5+2 \\ 2 & 3-21\end{array}$

Lamunan langkung ti misti Iringan lagu

\begin{tabular}{|c|c|c|c|c|c|c|c|c|}
\hline T.Ki & $\overline{5 \dot{4}}$ & $\dot{3}$ & $\dot{5}$ & $\overline{0 \ddot{2} \overline{0 \ddot{2}}}$ & $\overline{\overline{1} \overline{5} \dot{4}}$ & $\overline{\dot{30 \dot{2}}}$ & $\overline{\dot{3} \dot{2}}$ & $\overline{0 \dot{5} \overline{05}}$ \\
\hline T.Ka & $\overline{55 \overline{54}}$ & $\overline{34} \overline{34}$ & $\overline{\overline{5 \overline{5 i}} \dot{i} i}$ & $\overline{\dot{20} \overline{20}}$ & $i \overline{54}$ & 3432 & $32 \overline{12} \overline{34}$ & $5 \overline{5 i}$ \\
\hline
\end{tabular}

\begin{tabular}{|c|c|c|c|c|}
\hline T.Ki & $\overline{i \dot{4}}$ & $\dot{3}$ & $\dot{5}$ & $\dot{2}$ \\
\hline T.Ka & $\overline{5154}$ & $\overline{3434}$ & $\overline{5 \overline{51}} \overline{21}$ & 2 \\
\hline
\end{tabular}

Vocal

ïi் $\dot{5} \quad \dot{3} \dot{3} \dot{3} \dot{3} \dot{3} \dot{4} \quad \dot{3} \dot{2} \dot{3} \dot{2} \dot{1} \dot{2} \dot{2} \dot{2} \dot{3} \dot{3} \dot{4} \dot{5}$

paparinan tuturus galur turunan 


\begin{tabular}{|c|c|c|c|c|c|c|c|c|}
\hline T.Ki & 0 & 0 & 0 & $\overline{0 \dot{2}}$ & $\overline{\dot{3} \overline{23}}$ & $\overline{\overline{0 \dot{3}} \overline{\dot{2} 0}}$ & $\overline{32}$ & $\dot{5}$ \\
\hline T.Ka & 0 & 0 & 0 & $\overline{02}$ & $\overline{3 \overline{23}}$ & $\overline{5120}$ & $\overline{3212 \overline{34}}$ & 5 \\
\hline
\end{tabular}

c. Jalannya Sajian

Sajian lagu mangu-mangu dalam sajian ini di awali dengan pasieupan kemudian ke gelenyu dan masuk ke dalam vokal. Dalam sajian ini lagu mangu-mangu dimasukan pola tabuhan rincik.

4. Kaleon

a. Deskripsi Sajian

Lagu ini termasuk kedalam wanda papantunan. Tabuhan kacapi indung memainkan tabuhan kemprangan yang bermetrum tetap. Rumpaka lagu ini menggambarkan perbincangan suami \& istri tentang kegundahan tidak diberi keturunan. 
b. Notasi Lagu

\section{Kaleon}

$\begin{array}{llll}\text { Wanda } & \text { : Papantunan } & \text { Rumpaka } & \text { : Dian Hendrayana } \\ \text { Laras } & : \text { Pelog } & \end{array}$

\begin{tabular}{c|cccc|cccc|} 
T.Ki & 0 & 0 & 0 & $\dot{5}$ & $\overline{0 \dot{5}}$ & $\dot{5}$ & $\overline{5 \dot{5}}$ & $\overline{0 \dot{1}}$ \\
\hline T.Ka & 0 & $\overline{12}$ & $\overline{31}$ & $\overline{22}$ & $\overline{23}$ & $\overline{21}$ & $\overline{21}$ & $\overline{51}$
\end{tabular}

\begin{tabular}{c|cccc|cccc|} 
T.Ki & $\ddot{1}$ & $\ddot{1}$ & $\ddot{1}$ & $\dot{5}$ & $\overline{0 \dot{5}}$ & $\dot{5}$ & $\overline{5} \dot{5}$ & $\overline{0}$ \\
\hline T.Ka & $\overline{51}$ & $\overline{34}$ & $\overline{51}$ & $\overline{22}$ & $\overline{23}$ & $\overline{21}$ & $\overline{21}$ & $\overline{02}$
\end{tabular}

\begin{tabular}{c|cccc|cccc|} 
T.Ki & $\ddot{1}$ & $\ddot{1}$ & $\ddot{1}$ & $\dot{5}$ & $\overline{0 \dot{5}}$ & $\dot{5}$ & $\overline{5 \dot{5}}$ & $\overline{01}$ \\
\hline T.Ka & $\overline{35}$ & $\overline{12}$ & $\overline{31}$ & $\overline{22}$ & $\overline{23}$ & $\overline{21}$ & $\overline{21}$ & $\overline{51}$
\end{tabular}

\begin{tabular}{c|cccc|cccc|} 
T.Ki & $\ddot{1}$ & $\ddot{1}$ & $\ddot{1}$ & $\dot{5}$ & $\overline{0 \dot{5}}$ & $\dot{5}$ & $\overline{5 \dot{5}}$ & $\overline{01}$ \\
\hline T.Ka & $\overline{51}$ & $\overline{34}$ & $\overline{51}$ & $\overline{22}$ & $\overline{23}$ & $\overline{21}$ & $\overline{21}$ & $\overline{02}$
\end{tabular}

\begin{tabular}{c|cccc|cccc|} 
T.Ki & $\ddot{1}$ & $\ddot{1}$ & $\ddot{i}$ & $\dot{5}$ & $\overline{0 \dot{5}}$ & $\dot{5}$ & $\overline{5} \dot{5}$ & $\overline{0}$ \\
\hline T.Ka & $\overline{15}$ & $\overline{12}$ & $\overline{34}$ & $\overline{55}$ & $\overline{53}$ & $\overline{45}$ & $\overline{25}$ & $\dot{1}$
\end{tabular}

\begin{tabular}{|c|c|c|c|c|}
\hline T.Ki & 0 & 0 & i & $\dot{5}$ \\
\hline T.Ka & $\overline{5 \dot{5}}$ & $\dot{3}$ & $\overline{0 \dot{4}}$ & $\dot{2}$ \\
\hline
\end{tabular}




\section{Motif Pirigan Lagu}

\section{Pola A}

\begin{tabular}{c|cccc|} 
& & & & \\
T.Ki & & $\cdot$ & $\cdot$ & 5 \\
\hline T.Ka & $\overline{15}$ & 4 & $\overline{51}$ & i
\end{tabular}

\section{Pola B}

\begin{tabular}{|c|c|c|c|c|c|c|c|c|c|c|c|}
\hline T.Ki & • & & . & . & . & . & $\cdot$ & . & $\cdot$ & $0 i$ & 5 \\
\hline T.Ka & 0 & 3 & 21 & 21 & 21 & 21 & . & . & 3 & 04 & 2 \\
\hline
\end{tabular}

\begin{tabular}{c|ccc|}
\multicolumn{2}{c|}{ Pola C } \\
T.Ki & 1 & 1 & 1 \\
\hline T.Ka & 3 & 3 & 3
\end{tabular}

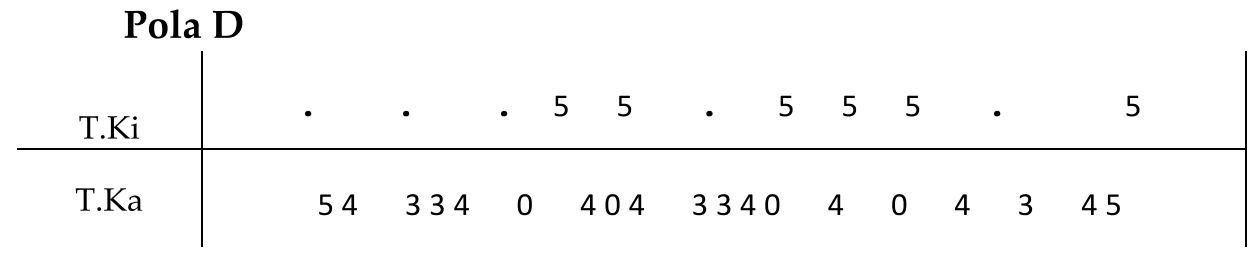

\begin{tabular}{c|cccccccccccccccccc}
\multicolumn{2}{c}{ Pola E } \\
T.Ki & & & & 5 & 5 & & 5 & 5 & $i$ & $i$ & & $i$ & 2 \\
\hline T.Ka & & 0 & 4 & 0 & 4 & 0 & 4 & 0 & 4 & 0 & 4 & 5 & 3 & 4 & 4 & 5
\end{tabular}


Lagu

Deudeuh eulis kembang asih

(Pola A + Pola B)

Geus lami nya sasarengan

(Pola A + Pola B)

Longkewang asa horeang

(Pola A + Pola B)

Lewang teuing rarasaan

(Pola A + Pola C)

kunaon mah duh engkang panutan ku asa melang

(Pola D)

Tos lami bangun nu liwung

(Pola C + Pola A)

Naon nu janten wagelan

(Pola E)

c. Jalannya Sajian

Kaleon disajikan penyaji dengan awalan dari gelenyu

kemudian masuk ke dalam sebuah lagu dengan menggunakan

tekhnik kemprangan yang berfungsi untuk mengiringi vokal. 


\section{Jemplang Pamirig}

a. Deskripsi Sajian

Lagu Jemplang Pamirig yaitu salah satu lagu dalam tembang sunda cianjuran yang termasuk kedalam wanda jejemplangan.

Rumpaka dari lagu ini menggunakan pola dari pupuh Asmarandana dengan guru wilangan dan guru lagu sebagai berikut: 8-1, 8-a, 8-e/o, 8-a, 7-a, 8-u, 8-a.

b. Notasi Lagu

\section{Jemplang Pamirig}

Wanda : Jejemplangan Rumpaka : Dian Hendrayana Laras : Degung

Gelenyu

\begin{tabular}{|c|c|c|c|c|c|c|c|c|}
\hline T.Ki $0 \overline{\overline{01}}$ & $\overline{0504}$ & $3 \overline{04}$ & 5 & $\overline{i \dot{1}} \overline{0 i}$ & $\overline{05} \overline{04}$ & $\overline{3 \overline{04}}$ & 5 & 1 \\
\hline T.Ka $\overline{01}$ & $\overline{54}$ & $\overline{\overline{33} \overline{34}}$ & $\overline{\overline{53} \overline{45}}$ & $\overline{01}$ & $\overline{54}$ & $\overline{33} \overline{34}$ & $\overline{\overline{5345}}$ & $\overline{\overline{32}}$ \\
\hline
\end{tabular}

\begin{tabular}{|c|c|c|c|c|c|c|c|c|}
\hline T.Ki & $\overline{0 \ddot{1} \overline{54}}$ & $\overline{\overline{04} 4}$ & $\overline{\dot{4} 4}$ & 3 & $\overline{0 \ddot{1} \overline{5} \dot{4}}$ & $\overline{\overline{0 \dot{4} \dot{4}}}$ & $\overline{\dot{4} 4}$ & 3 \\
\hline T.Ka & $\overline{\overline{123}} \overline{\overline{2}}$ & $\overline{45} \overline{45}$ & $\overline{45 \overline{43}}$ & $\overline{\overline{03}} \overline{32}$ & $\overline{\overline{123}}$ & $\overline{\overline{04} \overline{44}}$ & $\overline{\overline{3 \overline{34}} \overline{54}}$ & 0 \\
\hline
\end{tabular}




\begin{tabular}{|c|c|c|c|c|c|c|c|c|}
\hline T.Ki & $\overline{0 \ddot{1} \overline{5} \dot{4}}$ & $\overline{\overline{0 \dot{4} 4}}$ & $\overline{\dot{4} \dot{4}}$ & 3 & $\overline{\overline{0 \ddot{1}} \overline{\overline{5} \dot{4}}}$ & $\overline{\overline{0 \dot{4} \dot{4}}}$ & $\overline{\dot{4} 4}$ & $\dot{5}$ \\
\hline T.Ka & $\overline{\overline{123}} \overline{\overline{4}}$ & $5 \overline{45}$ & $\overline{\overline{45} \overline{43}}$ & $\overline{\overline{03}} \overline{32}$ & $\overline{\overline{123}}$ & $\overline{\overline{04} \overline{44}}$ & $\overline{334} \overline{54}$ & 5 \\
\hline
\end{tabular}

\begin{tabular}{c|cccc|} 
T.Ki & $\overline{1 \dot{5}}$ & $\dot{4}$ & $\overline{1 \dot{5}}$ & $\dot{4}$ \\
\hline T.Ka & $\overline{12 \overline{51}}$ & 4 & $\overline{\overline{34} \overline{23}}$ & 1
\end{tabular}

Pola Tabuh

\begin{tabular}{c|cccc|}
\multicolumn{2}{c|}{ Pola A } & & & \\
T.Ki & 0 & $\ddot{1}$ & $\dot{5}$ & $\dot{4}$ \\
\hline T.Ka & $\overline{01}$ & $\overline{12}$ & $\overline{34}$ & 1
\end{tabular}

\section{Pola B}

\begin{tabular}{l|cccc|} 
T.Ki & $\dot{4}$ & $\ddot{1}$ & $\dot{5}$ & 4 \\
\hline T.KaO $\overline{\overline{34}}$ & $\overline{03}$ & $\overline{02}$ & $\overline{34}$ & 1
\end{tabular}

\begin{tabular}{c|cccc|} 
Pola C & & & \\
T.Ki & $\dot{4}$ & $\dot{3}$ & $\dot{5}$ & $\dot{4}$ \\
\hline T.Ka $\overline{\overline{0} \overline{34}}$ & $\overline{03}$ & $\overline{02}$ & $\overline{34}$ & 1
\end{tabular}

\begin{tabular}{l|cccccccccc|} 
Pola D & & & & & & & & \\
T.Ki & $\dot{3}$ & $\ddot{1}$ & $\dot{3}$ & $\ddot{1}$ & $\dot{3}$ & $\ddot{1}$ & $\dot{3}$ & $\ddot{1}$ & $\dot{3}$ & 4 \\
\hline T.Ka & 0 & $\overline{33}$ & $\overline{33}$ & $\overline{33}$ & $\overline{33}$ & $\overline{33}$ & $\overline{33}$ & $\overline{32}$ & $\overline{34}$ & 1
\end{tabular}




\begin{tabular}{l|cccccccc|} 
Pola E & & & & & & & \\
T.Ki & $\dot{4}$ & $\ddot{1}$ & $\dot{4}$ & $\ddot{1}$ & $\dot{4}$ & $\ddot{1}$ & $\dot{4}$ \\
\hline T.Ka $\overline{\overline{04}}$ & $\overline{04}$ & $\overline{0 \overline{04}}$ & $\overline{04}$ & $\overline{44}$ & $\overline{44}$ & $\overline{44}$ & $\overline{44}$
\end{tabular}

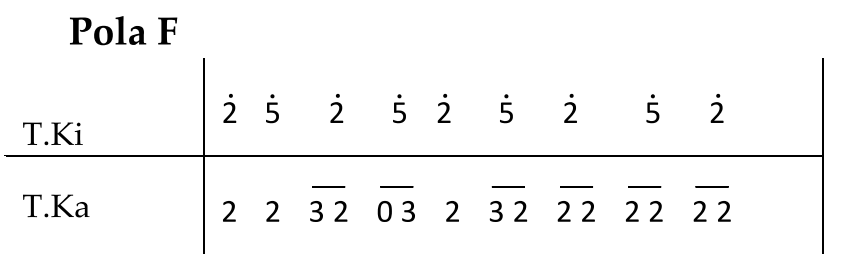

\begin{tabular}{l|llllll|}
\multicolumn{2}{c|}{ Pola G } & & & & & \\
T.Ki & $\ddot{1}$ & $\dot{4}$ & $\ddot{1}$ & $\dot{4}$ & $\dot{5}$ \\
\hline T.Ka & $\overline{44}$ & $\overline{32}$ & $\overline{12}$ & $\overline{34}$ & 5
\end{tabular}

\section{Lagu}

Pola A

Engkang mangga seug ngalahir

(Pola B dan Pola C diulang-ulang secara bergantian)

Balaka satarabasna

(Pola B dan Pola C diulang-ulang secara bergantian)

Ku abdi ge tos kabade

(Pola B dan Pola C diulang-ulang secara bergantian)

Seug mangga engkang mah wenang

(Pola D)

Kagungan manah midua

(Pola E)

Aduh enung ulah kitu

(Pola F) 
Kumaha kedah kumaha

\section{(Pola E dan Pola G)}

\section{Dangdanggula degung}

a. Deskripsi Sajian

Dangdanggula degung termasuk kedalam wanda dedegungan.

Pola tabuhan ini mengadopsi dari tabuhan gamelan degung.

Namun isi rumpaka mengikuti pola pupuh.

b. Notasi Lagu

\section{Dangdanggula Degung}

Wanda : Dedegungan Rumpaka :Dian Hendrayana Laras : Degung

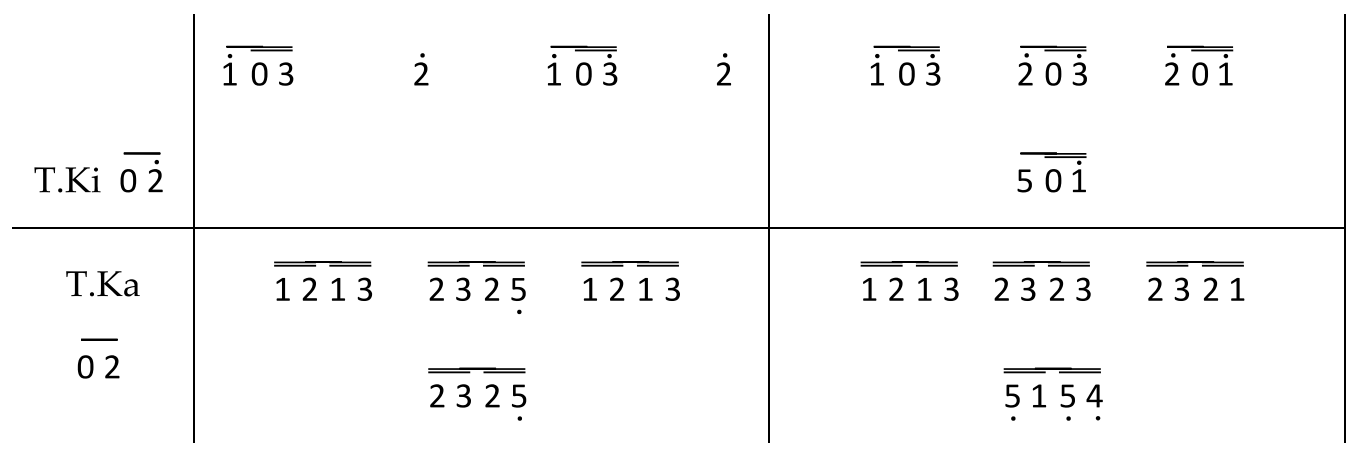




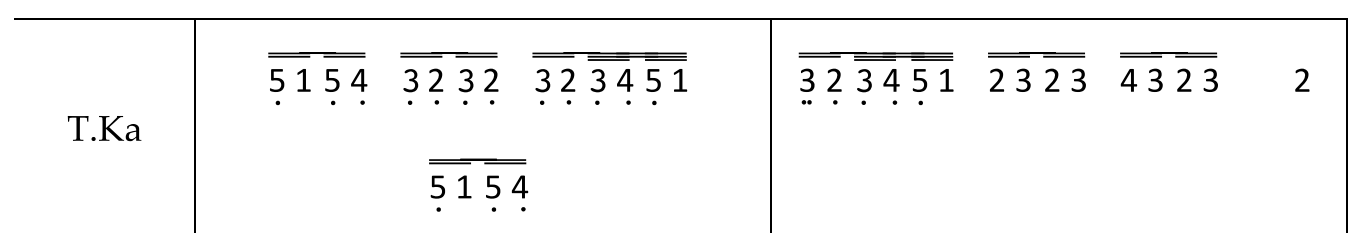

\begin{tabular}{|c|c|c|c|c|c|}
\hline T.Ki & $\dot{3}$ & $\overline{302}$ & $\overline{0 \overline{20}}$ & $\overline{\dot{5} \overline{0 \dot{5}}}$ & $\overline{\overline{0 \dot{5} \dot{5}} \dot{2}}$ \\
\hline T.Ka & $\overline{30343}$ & $3 \overline{0342}$ & $\overline{02 \overline{34}}$ & $\overline{5 i} \overline{5 i}$ & $\overline{\overline{515}} \overline{2 \overline{05}}$ \\
\hline
\end{tabular}

\begin{tabular}{|c|c|c|c|c|c|c|c|c|}
\hline T.Ki & 5 & $\dot{5}$ & $\overline{\dot{2} \overline{1} 5}$ & $\overline{\dot{304}}$ & $\overline{\dot{3} \dot{2}}$ & $\overline{\dot{3} \dot{2}}$ & $\overline{\dot{3} 2}$ & $\dot{5}$ \\
\hline T.Ka & $\overline{5 \overline{05} \overline{15}}$ & $\overline{5 \overline{05} \overline{13}}$ & $\overline{4512}$ & $\overline{334}$ & $\overline{32 \overline{32}}$ & $\overline{3 \overline{34}} \overline{\overline{52}}$ & $\overline{3 \overline{34}} \overline{\overline{54}}$ & $\overline{5 \overline{02}}$ \\
\hline
\end{tabular}

\begin{tabular}{c|cccc|} 
T.Ki & $\dot{2}$ & $\overline{i \dot{1}}$ & $\overline{34}$ & $\dot{5}$ \\
\hline T.Ka & $\overline{\overline{23} \overline{25}}$ & $\overline{\overline{1 \overline{12}} \overline{\overline{32}}}$ & $\overline{\overline{3 \overline{34}} \overline{\overline{54}}}$ & 5
\end{tabular}

Pola Tabuh

Pola Ambahan 5

\begin{tabular}{c|ccccccc|} 
T.Ki & \multicolumn{1}{|c|}{1} & 5 & & \\
\hline T.Ka & 5 & 5 & 5 & 5 & 45 & 54 & 43
\end{tabular}

Pola Ambahan 3

\begin{tabular}{|c|c|c|}
\hline T.Ki & 5 & 4 \\
\hline T.Ka & $\begin{array}{llll}3 & 3 & 3 & 3\end{array}$ & $\begin{array}{l}4 \\
4\end{array} 32$ \\
\hline
\end{tabular}




\begin{tabular}{|c|c|c|}
\hline \multicolumn{3}{|c|}{ Pola Ambahan 2} \\
\hline T.Ki & 2 & 3 \\
\hline T.Ka & 222 & $\begin{array}{lll}1 & 51 & 2\end{array}$ \\
\hline
\end{tabular}

\begin{tabular}{c|cccc|}
\multicolumn{3}{c}{ Pola Kulincer 5} \\
T.Ki & 5 & 4 & 4 & 5 \\
\hline T.Ka & 234 & 43 & 323 & 2345
\end{tabular}

\begin{tabular}{|c|c|c|c|}
\hline \multicolumn{4}{|c|}{ Pola Nunggu 5} \\
\hline T.Ki & $\dot{5}$ & $\dot{5}$ & $\dot{5}$ \\
\hline T.Ka & 55 & 55 & 55 \\
\hline
\end{tabular}

\begin{tabular}{|c|c|c|c|c|c|}
\hline \multicolumn{6}{|c|}{ Pola Nunggu 2} \\
\hline T.Ki & & $\dot{2}$ & $\dot{2}$ & $\dot{2}$ & \\
\hline T.Ka & 2 & 2 & 4 & 2 & 2 \\
\hline
\end{tabular}

\begin{tabular}{c|ccc|}
\multicolumn{2}{c}{ Pola Golosor 5} \\
T.Ki & 2 & 3 & 5 \\
\hline T.Ka & 511 & 512 & 2345
\end{tabular}

Pola Cindek
\begin{tabular}{l|llll|} 
T.Ki & 2 & 3 & 5 & $\dot{5}$ \\
\hline
\end{tabular}




\begin{tabular}{|l|llll|}
\hline T.Ka & 51 & 512 & 234 & 2345
\end{tabular}

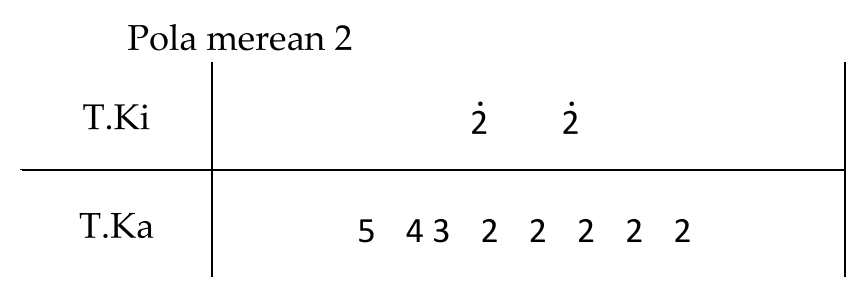

\begin{tabular}{c|cccc|}
\multicolumn{2}{c}{ Pola Liliwatan } \\
T.Ki & 2 & 3 & 5 & $\dot{2}$ \\
\hline T.Ka & 5.1 & 5123 & 34 & 432
\end{tabular}

\begin{tabular}{c|ccccccc|}
\multicolumn{2}{c|}{ Pola Santok } \\
T.Ki & 2 & 3 & 2 & 3 & 4 & 5
\end{tabular}

\begin{tabular}{c|cccc|}
\multicolumn{2}{c}{ Papagera Turun 2} & & & \\
T.Ki & 5 & 4 \\
\hline T.Ka & 4 & 3 & 3 & 2
\end{tabular}

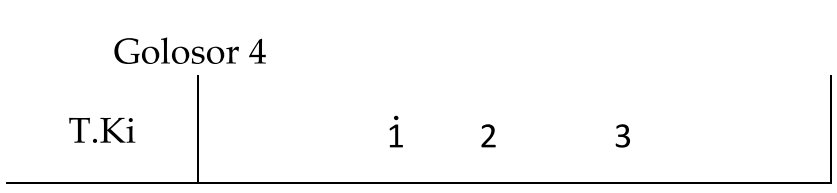


T.Ka

$45 \quad 5 i \quad 512$ 


\section{LAGU}

Nanging geuning $k u$ teu wasa mungkir

(Ambahan 5) + (Ambahan 3) + (kulincer 5)

Sesah pisan rek nyieuhkeunana

(nunggu 5) + (golosor 5)

Kunaon naha kunaon

(golosor 4) + (golosor 5)

Gandrung teu manggih tungtung

(nunggu 5$)+($ Ambahan 5$)+($ Ambahan 3$)+($ Golosor 5$)$

Nganti-nganti jimat awakiung

(Nunggu 5) + (Ambahan 2) + (Cindek)

(Nunggu 5) 432

c. Jalannya sajian

Lagu ini diawali dengan tabuhan jembatan penghubung sebelum masukkedalam lagu dangdanggula degung.

7. Panyalahan

a. Deskripsi Lagu

Panyalahan termasuk kedalam wanda rarancagan . lagu ini berlaras mandalungan atau surupan $3=\mathrm{T}$ 
b. Notasi Lagu

\section{Panyalahan}

$\begin{array}{llll}\text { Wanda } & \text { : Rarancagan } & \text { Rumpaka } & \text { : Dian Hendrayana } \\ \text { Laras } & : \text { Mandalung } & & \end{array}$

Pola Meran 1

\begin{tabular}{c|cccccccc|c|} 
T.Ki & i & & i & i & & \\
\hline T.Ka & 21 & 1 & 1 & 1 & 1 & 1 & 1 & 1
\end{tabular}

\begin{tabular}{|c|c|}
\hline \multicolumn{2}{|c|}{ Pola Liliwatan } \\
\hline T.Ki & 2 \\
\hline T.Ka & 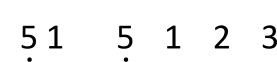 \\
\hline
\end{tabular}

Pola beulit 2

\begin{tabular}{c|rrrrr|} 
T.Ki & 5 & 5 & 5 & 4 & \\
\hline T.Ka & 234 & 4 & 434 & 43 & 32
\end{tabular}

\begin{tabular}{|c|c|c|}
\hline \multicolumn{3}{|c|}{ Pola merean 4} \\
\hline T.Ki & 4 & 4 \\
\hline T.Ka & $2 \quad 154$ & $4.4 \quad 4 \quad 4$ \\
\hline
\end{tabular}

\begin{tabular}{c|ccc|}
\multicolumn{2}{l}{ Pola golosor 3} \\
T.Ki & 5 & 1 & $i$ \\
\hline T.Ka & 3.4 & 3.45 & 5
\end{tabular}




\section{Pola Beulit 1}

\begin{tabular}{c|rrrrr|} 
T.Ki & 4 & 4 & 4 & 3 & \\
\hline T.Ka & 123 & 3 & 323 & 32 & 21
\end{tabular}

\section{Pola Merean 3}

\begin{tabular}{|c|c|c|c|c|c|c|}
\hline T.Ki & & 3 & & 3 & 3 & \\
\hline T.Ka & $i$ & 5 & 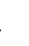 & & 33 & 33 \\
\hline
\end{tabular}

Pola Golosor 1

\begin{tabular}{c|ccc|} 
T.Ki & 3 & 4 & 4 \\
\hline T.Ka & 12 & 123 & 3
\end{tabular}

Pola Golosor 2

\begin{tabular}{c|ccc|} 
T.Ki & 4 & 5 & 5 \\
\hline T.Ka & 23 & 234 & 4
\end{tabular}

Pola Kulincer 5

\begin{tabular}{|c|c|c|c|c|}
\hline T.Ki & & 5 & 4 & 4 \\
\hline T.Ka & 234 & 43 & 323 & 2345 \\
\hline
\end{tabular}




\section{Pola Golosor 2}

\begin{tabular}{|c|c|c|}
\hline T.Ki & i & $\dot{2} \dot{2}$ \\
\hline T.Ka & & $45 i$ \\
\hline
\end{tabular}

Pola Beulit 4

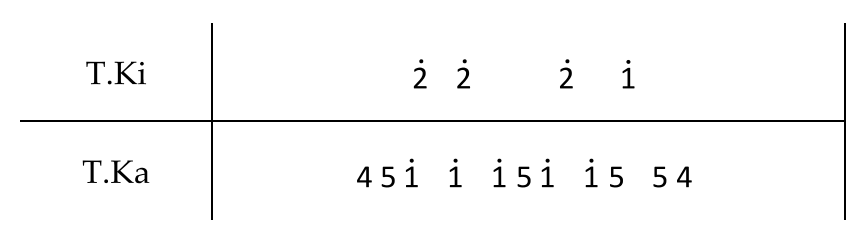

Papageran Turun 2

\begin{tabular}{|c|c|}
\hline T.Ki & 54 \\
\hline T.Ka & 4332 \\
\hline
\end{tabular}

Pola Nunggu 2

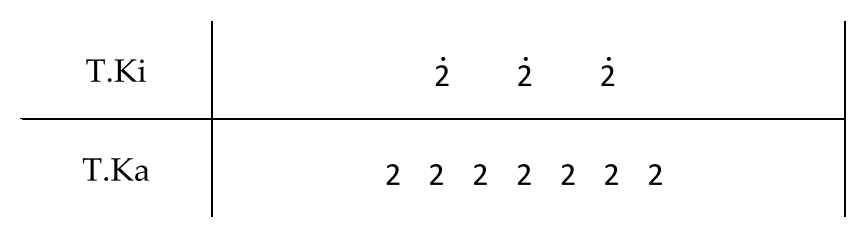

Pola Beulit 3

\begin{tabular}{|c|c|c|c|}
\hline T.Ki & i & 5 & $\dot{3}$ \\
\hline T.Ka & 345 & 54 & 43 \\
\hline
\end{tabular}


Lagu

Duh jungjunan sanes teu nyaah

(Merean 1) + (Liliwatan 1) + (Beulit 2)

Sareng sanes tos teu nyaah

$($ Merean 4$)+($ Golosor 3$)+($ Beulit 1$)$

Kajurung sewu impian

(Merean 3) + (Golosor 4)

Ku haying nyanding anaking

(Merean 3) + (golosor 2)

Nimang deungkleung buah ati

(merean 4) + (Beulit 4)

Jung engkang abdi jumurung

(Merean 3) + (Kulincer 5) + (Golosor 2$)$

Da puguh diri abdi mah

(meran 4) + (Beulit 4)

Sakieu nya gurat milik

(Merean 3) + (Golosor 2)

Wungkul dua (wungkul dua) tinekanan manggih bagja

(Merean 1) + (Papageran Turun 2) + (Kulincer 5) + (Golosor 2) 
8. Ngumbar asih

a. Deskripsi lagu

Lagu ngumbar asih merupakan salagh satu lagu dalam tembang sunda cianjuran yang berlara mandalungan atau mataraman, yaitu laras pelog dengan surupan $3=$ tugu. Lagu ngumbar asih juga termasuk kedalam kelompok wanda panambihdan termasuk kedalam lagu sekar tandak atau lagu bermetrum tetap

b. Notasi Lagu

\begin{tabular}{|c|c|c|c|c|c|c|c|c|}
\hline \multicolumn{9}{|c|}{ Ngumbar Asih } \\
\hline Wanda & \multirow{2}{*}{\multicolumn{3}{|c|}{$\begin{array}{l}\text { : Panambih } \\
\text { : Mandalungana }\end{array}$}} & & \multirow[t]{2}{*}{ Rumpaka } & \multicolumn{3}{|c|}{ : Dian Hendrayana } \\
\hline Laras & & & & & & & & \\
\hline Pangkat & & 32 & & & & & & \\
\hline T.Ka & 0 & $\overline{0 \dot{5} 0}$ & $\overline{0 \dot{5}} \overline{0 \dot{5}}$ & $0 \dot{3} \dot{3}$ & $\overline{3 \dot{3}}$ & $0 \dot{05}$ & $\overline{0 \dot{5} \dot{5}}$ & $\dot{3}$ \\
\hline T.Ki $\overline{02}$ & & & $\overline{i 2}$ & $\overline{52}$ & $\overline{i 2}$ & $\overline{52}$ & $\overline{i 2}$ & $\overline{32}$ \\
\hline T.Ka & 0 & $\overline{\overline{050}}$ & $\overline{\overline{05} \overline{05}}$ & $\overline{\overline{0 \dot{3}} \dot{3}}$ & $\overline{3 \dot{3}}$ & $\overline{\overline{0 \dot{5}} \overline{0 \dot{5}}}$ & $\overline{\dot{3}} \dot{5}$ & ( $\ddot{2})$ \\
\hline T.Ki & & & $\overline{22}$ & $\overline{52}$ & $\overline{22}$ & $\overline{52}$ & $\overline{22}$ & $\overline{35}$ \\
\hline
\end{tabular}




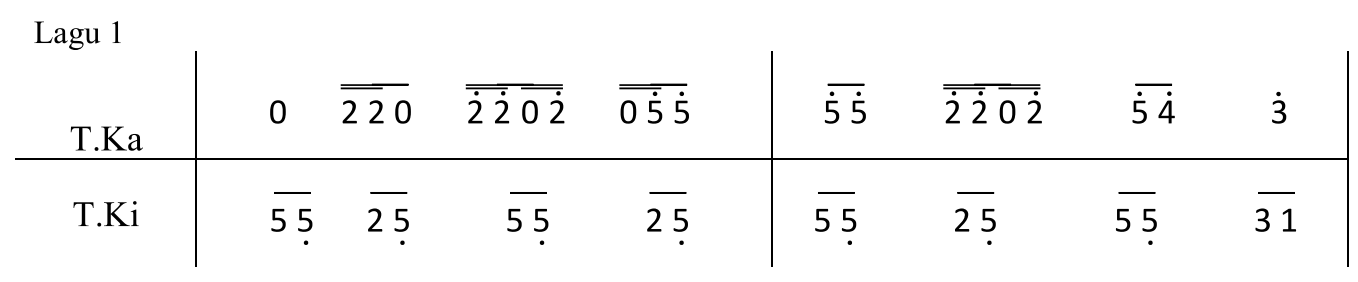

\begin{tabular}{c|cccc|cccc|} 
T.Ka & $\overline{0 \dot{5}}$ & $\dot{3}$ & $\overline{5 \dot{3}}$ & $\overline{0 \dot{5}}$ & $\dot{3}$ & $\overline{\dot{3} \dot{5} \overline{5}}$ & $\overline{\dot{3}}$ & 1 \\
\hline T.Ki & $\overline{11}$ & $\overline{51}$ & $\overline{11}$ & $\overline{51}$ & $\overline{11}$ & $\overline{51}$ & $\overline{11}$ & $\overline{02}$
\end{tabular}

\begin{tabular}{c|cccc|cccc|} 
T.Ka & 0 & $\overline{0 \dot{5} 0}$ & $\overline{0 \dot{5} \overline{0 \dot{5}}}$ & $\overline{\overline{0 \dot{3}}}$ & $\overline{\dot{3}}$ & $\overline{\overline{0 \dot{05}}}$ & $\overline{\overline{0 \dot{5}}}$ & $\dot{3}$ \\
\hline T.Ki & $\overline{22}$ & $\overline{52}$ & $\overline{22}$ & $\overline{52}$ & $\overline{22}$ & $\overline{52}$ & $\overline{22}$ & $\overline{\dot{32}}$
\end{tabular}

\begin{tabular}{|c|c|c|c|c|c|c|c|c|}
\hline T.Ka & 0 & $\overline{\overline{0 \dot{5}} 0}$ & $\overline{\overline{0 \dot{5}} \overline{0 \dot{5}}}$ & $\overline{\overline{0 \dot{3}} \dot{3}}$ & $\overline{\dot{3} \dot{3}}$ & $\overline{0 \dot{05}} \overline{0 \dot{5}}$ & $\overline{\overline{0 \dot{5}} \dot{5}}$ & $(\ddot{2})$ \\
\hline T.Ki & $\overline{\dot{2} 2}$ & $\overline{52}$ & $\overline{22}$ & $\overline{52}$ & $\overline{\dot{2} 2}$ & $\overline{52}$ & $\overline{i 2}$ & $\overline{35}$ \\
\hline
\end{tabular}

\begin{tabular}{c|cccc|cccc|} 
Telenyu & 0 & $\overline{0 \dot{5} 0}$ & $\overline{0 \dot{5} \overline{0 \dot{5}}}$ & $\overline{\overline{0 \dot{3}}}$ & $\overline{\dot{3} \dot{3}}$ & $\overline{0 \dot{5} \overline{0 \dot{5}}}$ & $\overline{\overline{0 \dot{5}}}$ & $\dot{3}$ \\
\hline T.Ki & $\overline{22}$ & $\overline{52}$ & $\overline{\dot{2} 2}$ & $\overline{52}$ & $\overline{\dot{2}}$ & $\overline{52}$ & $\overline{\dot{2}}$ & $\overline{\dot{3} 2}$
\end{tabular}

\begin{tabular}{c|cccc|cccc|}
$\mathrm{T.Ka}$ & 0 & $\overline{\overline{0 \dot{5} 0}}$ & $\overline{\overline{0 \dot{5}} \overline{0 \dot{5}}}$ & $\overline{\overline{0 \ddot{3}}}$ & $\overline{3 \ddot{3}}$ & $\overline{\overline{0 \dot{5}} \overline{0 \dot{5}}}$ & $\overline{3 \dot{5}}$ & $(\ddot{2})$ \\
\hline T.Ki & $\overline{\dot{2} 2}$ & $\overline{52}$ & $\overline{\dot{2} 2}$ & $\overline{52}$ & $\overline{\dot{2} 2}$ & $\overline{52}$ & $\overline{\dot{2}}$ & $\overline{\dot{35}}$
\end{tabular}




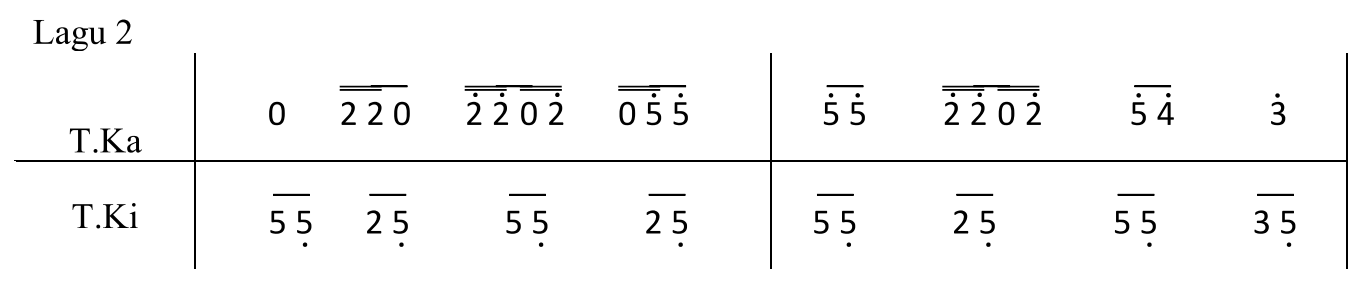

\begin{tabular}{|c|c|c|c|c|c|c|c|c|}
\hline T.Ka & $\overline{0 \dot{2}}$ & $\overline{\overline{32}} \overline{0 \dot{3}}$ & $\overline{\overline{0 \dot{2}} \overline{3 \dot{2}}}$ & $\overline{\overline{0 \dot{3}} \dot{3}}$ & $\overline{2 \dot{3}}$ & $\overline{\overline{0 \ddot{1} \ddot{1}}}$ & $\overline{1} \dot{5}$ & $\ddot{5}$ \\
\hline T.Ki & $\overline{55}$ & $\overline{35}$ & $\overline{55}$ & $\overline{35}$ & $\overline{55}$ & $\overline{35}$ & $\overline{55}$ & $\overline{04}$ \\
\hline
\end{tabular}

\begin{tabular}{|c|c|c|c|c|c|c|c|c|}
\hline T.Ka & 0 & $\overline{\overline{2} \ddot{2} 0}$ & $\overline{\overline{2} \ddot{2} \overline{0 Z}}$ & $\overline{\overline{055}}$ & $\overline{55}$ & $\overline{\overline{2} \ddot{z} 0 \ddot{z}}$ & $\overline{\overline{5} \ddot{z}}$ & $\ddot{4}$ \\
\hline T.Ki & $\overline{\dot{4} 4}$ & $\overline{34}$ & $\overline{\dot{4} 4}$ & $\overline{34}$ & $\overline{\dot{4} 4}$ & $\overline{34}$ & $\overline{\dot{4} 4}$ & $\overline{04}$ \\
\hline
\end{tabular}

\begin{tabular}{c|cccc|cccc|} 
T.Ka & $\overline{0 \ddot{2}}$ & $\overline{5 \ddot{2}}$ & $\overline{4 \ddot{2}}$ & $\ddot{3}$ & 0 & $\overline{\overline{3} \dot{5} \overline{0}}$ & $\overline{\overline{3} \dot{5}}$ & $\ddot{1}$ \\
\hline $\mathrm{T} . \mathrm{Ki}$ & $\overline{\dot{4} 4}$ & $\overline{34}$ & $\overline{\dot{44}}$ & $\overline{31}$ & $\overline{i 1}$ & $\overline{41}$ & $\overline{11}$ & $\overline{02}$
\end{tabular}

\begin{tabular}{c|cccc|cccc|} 
T.Ka & 0 & $\overline{0 \dot{5} 0}$ & $\overline{\overline{0 \dot{5}} \overline{0}}$ & $\overline{\overline{0 \dot{3}}}$ & $\overline{3 \ddot{3}}$ & $\overline{0 \dot{0 \dot{5}}}$ & $\overline{\overline{0 \dot{5}}}$ & $\ddot{3}$ \\
\hline $\mathrm{T} . \mathrm{Ki}$ & $\overline{\dot{2} 2}$ & $\overline{52}$ & $\overline{\dot{2}}$ & $\overline{52}$ & $\overline{\dot{2}}$ & $\overline{52}$ & $\overline{\dot{2} 2}$ & $\overline{\dot{3} 2}$
\end{tabular}

\begin{tabular}{c|cccc|cccc|} 
T.Ka & 0 & $\overline{\overline{050}}$ & $\overline{\overline{0 \dot{5}} \overline{0 \dot{5}}}$ & $\overline{\overline{0 \dot{3}}}$ & $\overline{3}$ & $\overline{\overline{3}} \overline{\overline{3}}$ & $\overline{\dot{3}}$ & $\ddot{2}$ \\
\hline T.Ki & $\overline{\dot{2} 2}$ & $\overline{52}$ & $\overline{\dot{2} 2}$ & $\overline{52}$ & $\overline{\dot{2} 2}$ & $\overline{52}$ & $\overline{\dot{2} 2}$ & $\overline{\dot{3} 2}$
\end{tabular}




\begin{tabular}{c|cccc|cccc|}
\multicolumn{2}{l}{$\begin{array}{l}\text { Ngeureunkeun } \\
\text { T.Ka } \overline{0 \dot{5}}\end{array} \overline{\overline{5} \dot{5}}$} & $\ddot{3}$ & $\overline{5 \ddot{3}}$ & $\overline{0 \dot{5}}$ & $\ddot{3}$ & $\overline{\overline{3} \dot{5} \overline{5}}$ & $\overline{3 \dot{5}}$ & $\ddot{2}$ \\
\hline $\mathrm{T} . \mathrm{Ki}$ & $\overline{\dot{2} 2}$ & $\overline{52}$ & $\overline{\dot{2} 2}$ & $\overline{52}$ & $\overline{\dot{2}}$ & $\overline{52}$ & $\overline{\dot{2}}$ & $\overline{02}$
\end{tabular}

Rumpaka

Duh jungjunan buah manah

Teu wasa engkang teu wasa

Nanging dalah dikumaha

Dikalang goda rancana

Kalah matak janten lewang

Naha lewang ulah ringrang

Bilih matak jadi bingbang

Geus digurit ti Yang Widi

Palias kedah ngolembar

Nun Gusti kiatkeun abdi

Tumampi sumerah diri

c. Jalannya sajian

Lagu ini tersambung dengan lagu sebelumnya tanpa di awali dengan pangkat.

9. Udan mas

a. Deskripsi Lagu

Lagu udan mas termasuk kedalam wanda rarancagan dengan laras madenda/sorog. Pada lagu ini, menceritakan pemeran salaki bertemu dengan pemeran gadis yang tidak lain adalah rekan kantornya, salaki diceritakan sedang memikirkan gadis tersebut dan 
sebaliknya, gadis itu pun sedang memikirkan pemeran salaki di tempat yang berbeda.

b. Notasi Lagu

\section{Udan Mas}

$\begin{array}{llll}\text { Wanda } & : \text { Rarancagan } & \text { Rumpaka } & \text { : Dian Hendrayana } \\ \text { Laras } & : \text { Madenda/Sorog } & & \end{array}$

Gelenyu 1

\begin{tabular}{|c|c|c|c|c|c|c|c|c|c|}
\hline T.Ki & $\ddot{2}$ & 0 & $\overline{0 \overline{50}}$ & $\overline{0 \overline{50}}$ & $\overline{0 \overline{50}}$ & 0 & $\ddot{3}$ & 0 & $\overline{0 \overline{0 \dot{5}}}$ \\
\hline T.Ka & $\overline{\overline{0 \dot{2}} \dot{2}}$ & $\overline{2} \dot{2}$ & $\overline{\dot{204}}$ & $\overline{3 \overline{04}}$ & $\overline{\dot{3} \overline{04}}$ & $\overline{\overline{\dot{3} \dot{2}} \overline{\dot{3} \dot{2}}}$ & $\overline{\overline{0 \dot{3}} \dot{3}}$ & $\overline{\dot{3} 3}$ & $\overline{\dot{3} \overline{30}}$ \\
\hline
\end{tabular}

\begin{tabular}{|c|c|c|c|c|c|c|c|c|c|}
\hline T.Ki & $\overline{04}$ & $\overline{0 \dot{5} \overline{05}}$ & $\overline{0 \dot{4}}$ & 0 & $\ddot{2}$ & 0 & $\overline{\dot{5} \ddot{1}}$ & $\overline{2} \ddot{3}$ & $\overline{0 \ddot{4}}$ \\
\hline T.Ka & $\overline{\overline{4} \dot{3} \overline{03}}$ & $\overline{\overline{40} \dot{3}}$ & $\overline{\dot{4} \dot{3} \overline{0}}$ & $\overline{\dot{2} \overline{2 \dot{3}}}$ & $\overline{\overline{02} \dot{2}}$ & $\overline{\dot{2} \overline{2}}$ & $\overline{0 \dot{5} \overline{0 \dot{1}}}$ & $\overline{\overline{0 \dot{2}} \dot{3}}$ & $\overline{\overline{04} \overline{4 \overline{04}}}$ \\
\hline
\end{tabular}

\begin{tabular}{|c|c|c|c|c|c|c|}
\hline T.Ki & $\overline{04}$ & 0 & $\overline{0 \ddot{2} \overline{0 \ddot{z}}}$ & $\overline{0 \ddot{1}}$ & 0 & \\
\hline T.Ka & $\overline{\overline{0 \dot{4}} \dot{4}}$ & $\overline{\dot{4} \dot{5}}$ & $\ddot{10} \overline{\overline{1}}$ & $\overline{0 \dot{5}}$ & $\overline{10 \dot{5}} \overline{0 \dot{5}}$ & $\dot{4 \dot{4}}$ \\
\hline
\end{tabular}

\section{Lagu}

Sok mindeng ngahuleng jentul

(Nunggu 4$)+($ Beulit 5) + (Papageran turun 2$)+($ Golosor 5$)$ 
Saban emut ka nu manis (geuning)

$($ merean 2$)+($ Nunggu 2$)+($ Beulit 1$)+($ Papageran Turun 2$)+($ Golosor 4$)$

$+($ Nunggu 4$)+($ Beulit 3$)+($ Gulung 2$)+($ Papageran Turun 4$)$

\section{Gelenyu}

Dicipta janten lamunan

(Merean 2$)+($ Nunggu 2$)+($ Beulit 1$)+($ gulung 2$)+($ Golosor 2$)$

(gandrung) kalah rangsak kana batin, da kana batin

(Nunggu 5) + (Papageran Turun 3) + (Golosor 3)

\section{Gelenyu}

Da puguh abdi sarua

$($ meran 4$)+($ Nunggu 4$)+($ Beulit 3$)+($ Papageran Turun 2$)+($ Golosor 4$)$

(gandrung) naha kalah ngait pikir

$($ Nunggu 2$)+($ Golosor 5$)+($ Beulit 4$)+($ Papageran Turun 3$)($ Golosor 2$)$

c. Jalannya Sajian

Penyajian lagu udan mas diawali dengan gelenyu sebelum ke repertoar lagu utama. 


\section{DAFTAR PUSTAKA}

Herdini, Heri. 2003. Metode Pembelajaran Kacapi Indung Dalam Tembang Sunda Cianjuran. Bandung: STSI PRESS.

Pratami, Jheinitta Ayu. 2018. “Masieup Rasa Tunggara." Skripsi Prodi Karawitan Fakultas Seni Pertunjukan. Bandung: ISBI Bandung.

De vale, Sue Carole. 1990. Organizing Organology. Los Angeles: University of California.

Soewargana, Oejeng. 1977. Gending Karesmen. Bandung: Gananco NV.

Sukanda, Enip. 2016. Riwayat Pemebntukan dan Perkembangan Cianjuran. Bandung: Disparbud Jawa Barat Yayasan Pancaniti.

Wiartmadja, Apung S. 1996. Mengenal Seni Tembang Sunda. Bandung: CV. Wahana Iptek.

Wiradiredja, Moh.Yusuf. 2000. Peranan Tembang Sunda Cianjuran dalam Gending Karesmen Lutung Kasarung. Yogyakart: UGM Yogyakarta.

_ _ _ 2014. Tembang Sunda Cianjuran di Priangan. Bandung: Sunan Ambu Press.

Nugraha, Asep. 2007. "Pemain Kacapi Indung Seni Tembang Sunda Cianjuran: Kajian Peraihan Derajat Kompetensi." Laporan Penelitian Beasiswa Unggulan. Bandung: STSI Bandung.

- - - 2015. "Penelusuran Perkembangan Kacapi Sunda." Jurnal Parguna Vol. 2 No. 1. Bandung: Prodi Karawitan Fakultas Seni Pertunjukan ISBI Bandung, 130-43. 


\section{GLOSARIUM}

Bubuka

Dedegungan

Gelenyu

Juru Mamaos
: lagu pembuka dalam sajian tembang Sunda

cianjuran, biasanya hanya instrumen saja.

: salah satu kelompok lagu dalam tembang Sunda cianjuran, yang tercipta dari pengolahan seni galmelan degung.

: komposisi iriungan lagu yang berfungsi sebagai tanda atau identitas dari lagu itu sendiri (pengertian gelenyu pada lagu tembang sunda cianjuran yang berirama merdeka). Sedangkan gelenyu pada lagupanambih (tandak) dalam tembang sunda cianjuran adalah sajian instrumentalia sebagai selingan untuk memberikan kesempatan istirahat kepada penembang.

: salah satu wanda dalam tembang Sunda cianjuran.

: isitilah vokalis tembang Sunda cianjuran. 
Kacapi Indung : : alat musik petik asal Jawa Barat, berbentuk seperti

perahu. Menggunakan 18 dawai, menggunakan dawai kuningan.

Kacapi Rincik $\quad$ : alat musik petik berukuran lebih kecil dari kacapi indung,

jumlah dawai berjumlah 15 yang terbuat dari stainles.

Mamaos

: tembang Sunda langgam cianjuran, berirama bebas

merdeka atau berirama bebas.

Mandalungan : salah satu laras dalam penyajian tembang Sunda

cianjuran.

Pamirig : penabuh waditra dalam tembang Sunda cianjuran.

Panambih : salah satu wanda dalam tembang Sunda cianjuran.

Papantunan : salah satu wanda tembang Sunda cianjuran.

Rumpaka : istilah syair atau lirik lagu. 
Salendro

Suling

Surupan

Wanda
: salah saru jenis tangga nada atau scale Sunda.

: alat musik tiup asal Jawa Barat terbuat dari bamboo, dan dilubangi beberapa bagian.

: istilah nada dasar yang diukur dari panjang

ukuran suling dalam tembang Sunda cianjuran.

: alat musik atau instrument.

: klasifikasi lagu atau genre dalam tembang Sunda

cianjuran. 


\section{LAMPIRAN}

\section{Lampiran 1. Naskah Cerita Dua Teu Sarasa}

\section{Naskah DUA TEU SARASA}

Disusun oleh : Dian Hendrayan

SALAKI KAKARA MULANG TI KANTOR. SUP KA IMAH. PAMAJIKANANA GEUS NYAMPAK MAPAGKEUN.

\section{KAPEURIH}

RAMPAK : Kunaon asa bayeungyang asa lanjung pipikiran kunaon asa kareunang $\mathrm{ku}$ teu puguh rarasaan

: Asa tara ti sasari rarungsing lain ti misti boa lungsé rudet haté mugi ulah nerus ati

NARATOR : Hirup dina jaladri rumah tangga éstuning teu weléh reureundahan sakapeung ngangkleung na lirihna cai nu tingtrim sakapeung ngoléab dina motahna ombak nu bedang kitu, saban waktu piligenti saban wanci tumut kana titis tulisna ajali kari kapancegan metakeun kadali jadi nakhoda, di satengahing legana sagara, nu tanpa tepi

\section{Adegan 1}

SALAKI KEUR NGOBROL DI IMAH JEUNG PAMAJIKANANA, NGEUNAAN HIRUP RUMAH TANGGA NU GEUS MEH NINCAK DUA BELAS TAUN

SALAKI ANTENG NGALANGEU SALILA-LILA. NIMBANG-NIMBANG PUTUSAN ANTARA MIHAREP ANAK, NYIAR DEUI PIPAMAJIKANEUN, JEUNG TETEP MANEUH JEUNG PAMAJIKANANA NU AYEUNA. MEUSMEUS NGARERET KA PAMAJIKANANA 


\section{MANGU-MANGU}

SALAKI

: Sok mindeng jadi pikiran

lalamunan beurang peuting

mikangen leunjeur rundayan

pameungkeut jatining asih

utun inji buah ati

dirangkulan dilalahun, deudeuh

duh Gusti Nu Maha Héman

lamunan langkung ti misti

paparinan (paparinan) tuturus galur turunan

NARASI $\quad$ : (MONOLOG, SORA HATÉ SALAKI)

Nun Gusti Nu Maha Asih

paparin abdi sareng pun bojo

turunan pameungkeut deudeuh

rundayan pamatri asih

sangkan deudeuh tambih pageuh

sangkan asih tambih meulit dina ati

\section{KALÉON}

Deudeuh eulis kembang asih

geus lami nya sasarengan

longkéwang asa haroong

lewang teuing rarasaan

PAMAJIKAN : kunaon (mah, duh engkang panutan) ku asa melang tos lami bangun nu liwung

naon nu janten wagelan?

\section{JEMPLANG PAMIRIG}

Engkang mangga seug ngalahir

balaka satarabasna

ku abdi gé tos kabadé

seug mangga engkang mah wenang

kagungan manah midua

SALAKI $\quad$ : aduh enung, aduh enung ulah kitu

kumaha kedah kumaha

(kumaha mah geuning, kedah kumaha?) 
SALAKI NGUSAP DEUDEUH KA PAMAJIKANANA.

SALAKI DIRUNGRUMAN MARUDAH RASA, MICILEUK HAYANG BOGA ANAK.

\section{DANGDANGGULA DEGUNG}

SALAKI

: Nanging geuning ku teu wasa mungkir sesah pisan rék nyieuhkeunana

kunaon naha kunaon

gandrung teu manggih tungtung

nganti-nganti jimat awaking

tapi geuning bet taya

iwal ukur lamun

sakapeung sok janten lewang

hayang teuing macangkrama sukaseuri

bagja cara nu lian

\section{PANYALAHAN}

SALAKI : Duh jungjunan sanés teu nyaah sareng sanés tos teu asih kajurung séwu impian ku hoyong nyanding anaking nimang dengkleung buah ati

PAMAJIKAN : jung engkang abdi jumurung da puguh diri abdi mah sakieu nya gurat milik wungkul du'a (wungkul du'a) tinekanan manggih bagja

\section{NGUMBAR ASIH}

SALAKI

: Duh jungjunan buah manah teu wasa engkang teu wasa nanging dalah dikumaha dikalang goda rancana kalah matak janten lewang

PAMAJIKAN : Naha lewang ulah ringrang bilih matak jadi bingbang geus digurit ti Yang Widi palias kedah ngolembar nun Gusti kiatkeun abdi tumampi sumerah diri 
Adegan 2

NARASI : Sora kalbu ngagumuruh milah milih kereteg sarwanaing kahayang nangtukeun kudu jeung ulah antara ngeukeuhan kanyaah jeung ngaranggeum tresna nu anyar

DI TAMAN KANTOR. SALAKI NYAMPEURKEUN KA RISMA

\section{UDAN MAS}

SALAKI

: Sok mindeng ngahuleng jentul saban émut ka nu manis (geuning) dicipta janten lamunan (gandrung) kalah rangsak kana batin, da kana batin

RISMA : da puguh abdi sarua (gandrung) naha kalah ngait piker

\section{RAHWANA GANDRUNG}

SALAKI : Duh jungjunan panyileukan beurang peuting pamentangan kembang asih pangimpian naha kalah manteng kangen, geuning tambih kapiangen duh... inggis kantun liwung sok sieun dirungrum bingung

RISMA : Aduh akang kantenan abdi teh lewang kumalangkang salebeting lelembutan naha kalah seseblakan, geuning tambih lelenyapan duh... inggis pupulasan sok sieun mung saliwatan

SALAKI : Ieuh geulis engkang deuk balaka saban dinten manteng baé ka salira ngalangkang dina lamunan ngalayang kokolébatan geuning teu ilang-ilang

Mun kamanah engkang rék mileuleuheungkeun nyangreud deudeuh migeugeut salalawasna urang seumat kaasih ku jatukrami Jungjunan... ku jatukrami

RISMA : Duh engkang deudeuh panutan saban dinten kapiraray kapicangcam 
teu langkung kuma kapalay

teu langkung abdi ngiringan

abdi moal rék baha

Mung panginten mugia kasaluyuan

nu sapalih boh bilih kalalangkungan

saéna mah putusan beurat timbangan

panutan asak timbangan

RISMA JADI SALAH TINGKAH.

Adegan 3

\section{PAMURAGAN}

SALAKI : Upami Jungjunan widi engkang rék wakca balaka maheutkeun asih jeung sono disimpay ku tali nikah

RISMA : (gandrung) sumangga abdi ngiringan mung baé aya panuhun (gandrung) nu itu saé dipisah

SALAKI BINGUNGEUN MUN KUDU NYERAHKEUN PAMAJIKANANA. RISMA TULUY LALAUNAN NINGGALKEUN. NGAJAUHAN

\section{MELANG BINGBANG}

SALAKI Melang melang naha melang kunaon abi melang bingbang bingbang geuning bingbang kunaon ku asa bingbang

Naha kapidangdung matak ngalanglayung naha janten lanjung, kalah tambih liwung naha kapidangdung matak ngalanglayung matak janten ngungun, geuning asa tambih nguyung

\section{RENGSE}




\section{Lampiran 2. Dokumentasi Karya Seni}

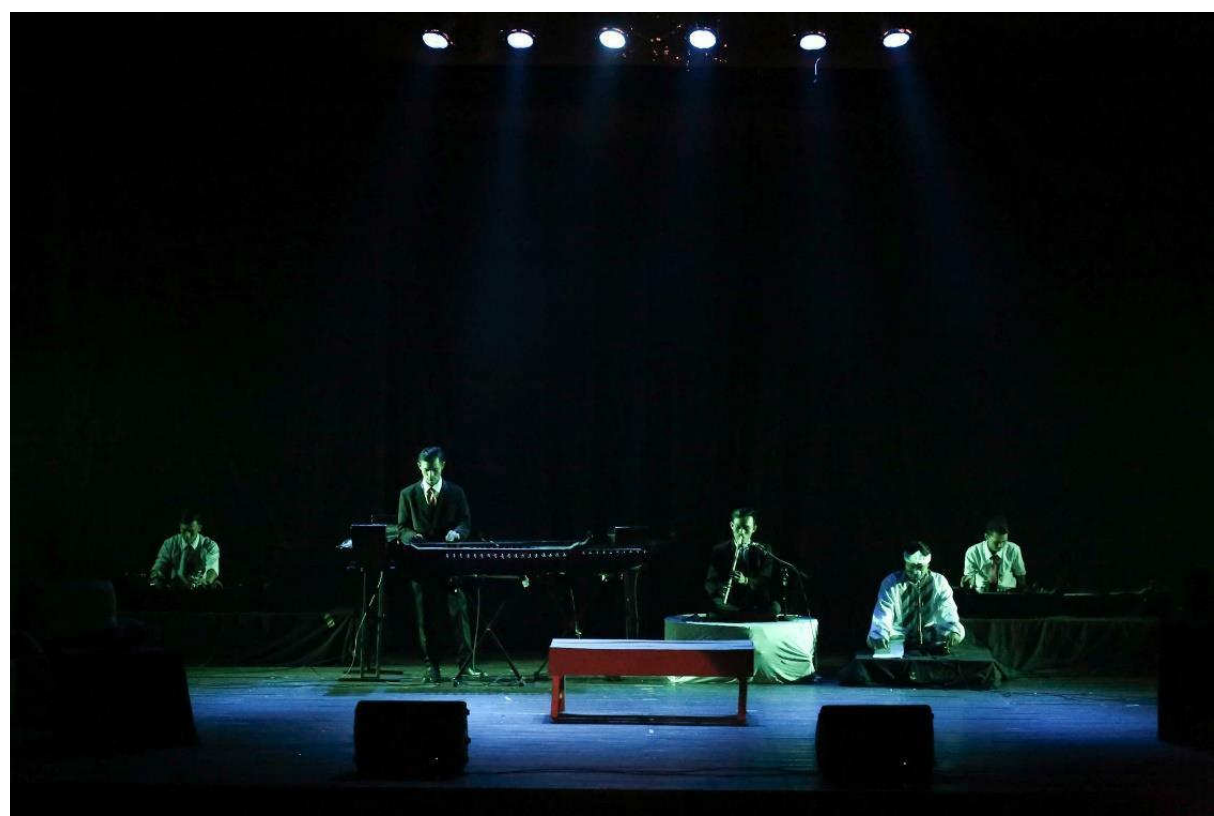

Lampiran Gambar 6. Dokumentasi saat hari H, tanggal 21 Juni 2019

(Dokumentasi: Herfan Rusando, 2019)

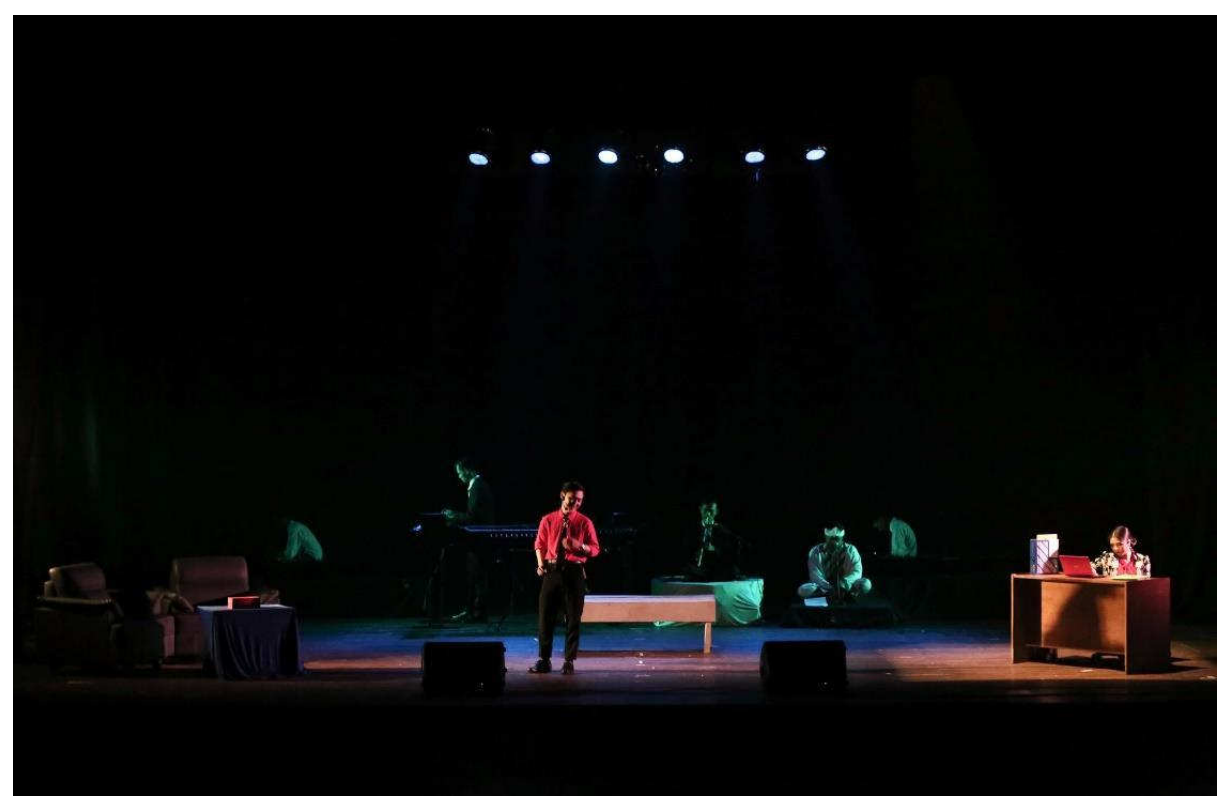

Lampiran Gambar 7. Adegan saat salaki akan bertemu Risma.

(Dokumentasi: Herfan Rusando, 2019) 


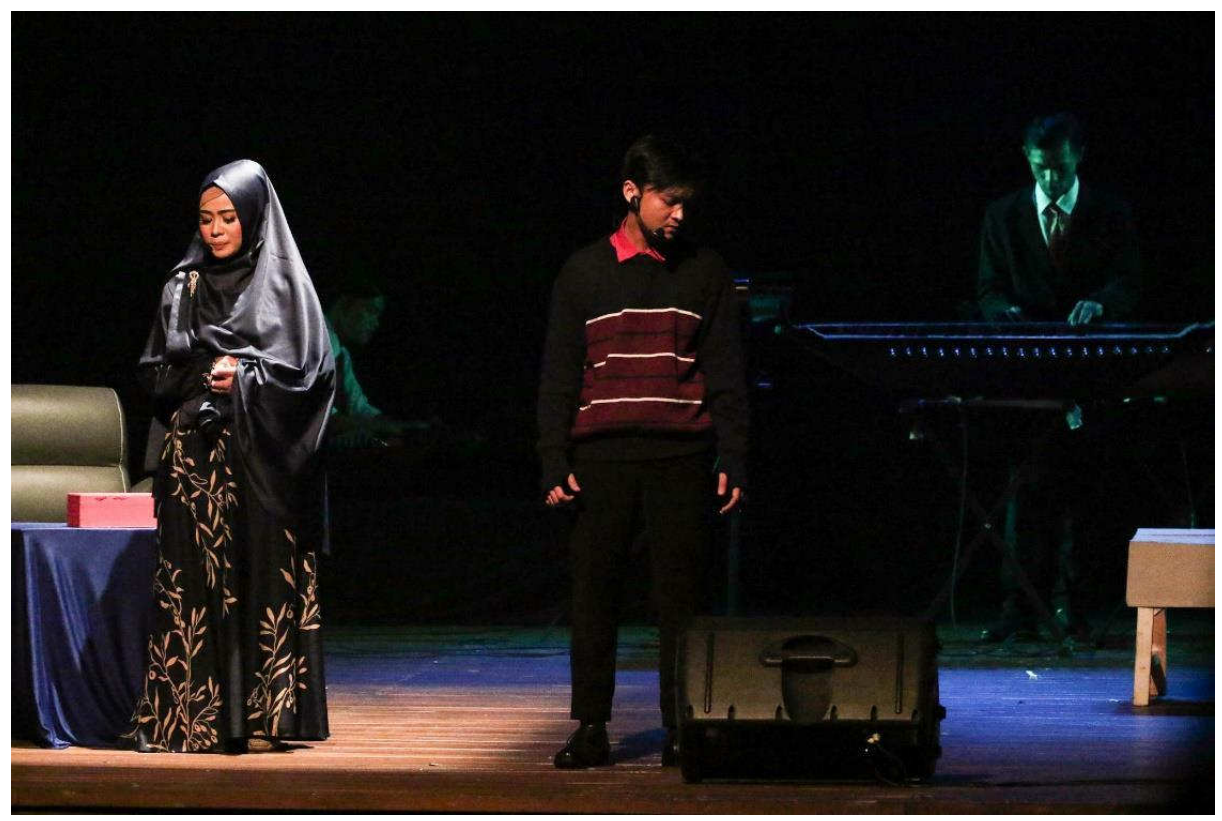

Lampiran Gambar 8. Adegan salaki bersama pamajikan.

(Dokumentasi: Herfan Rusando, 2019)

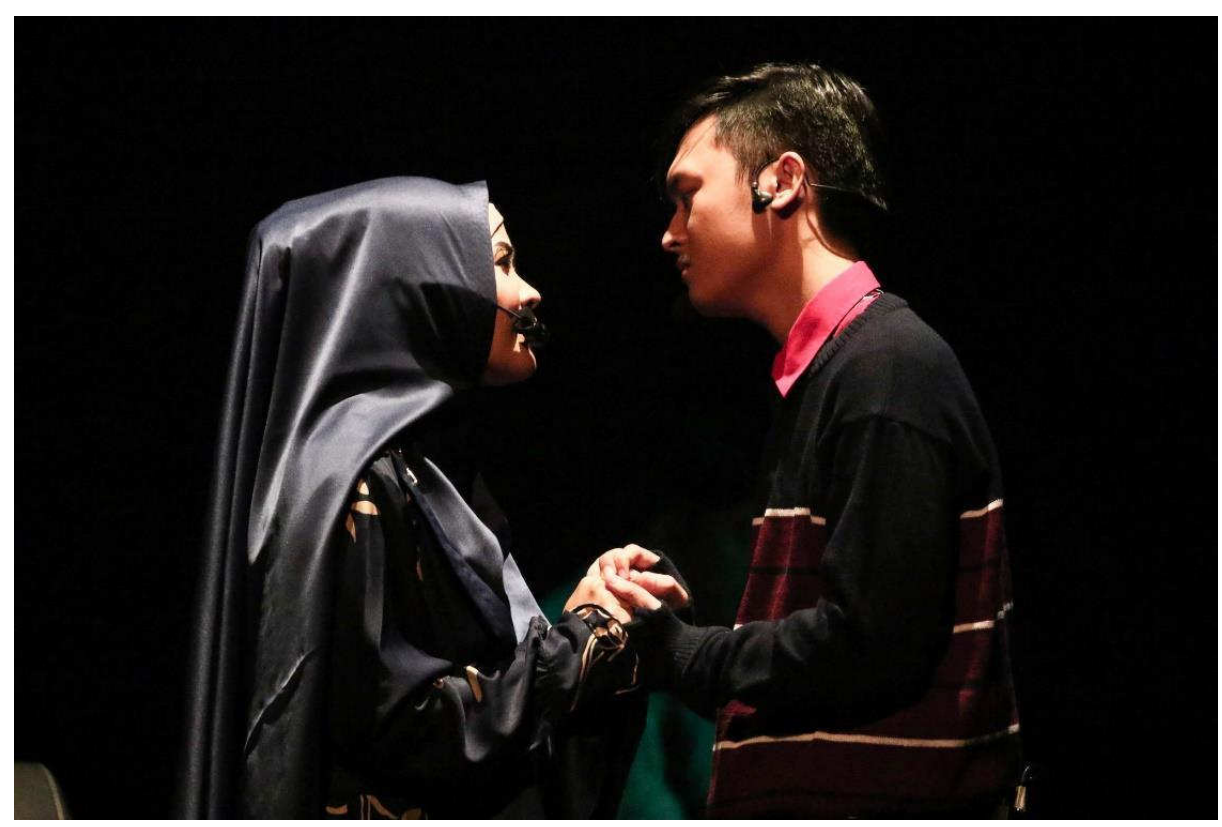

Lampiran Gambar 9. Adegan salaki akan meninggalkan pamajikan.

(Dokumentasi: Herfan Rusando, 2019) 


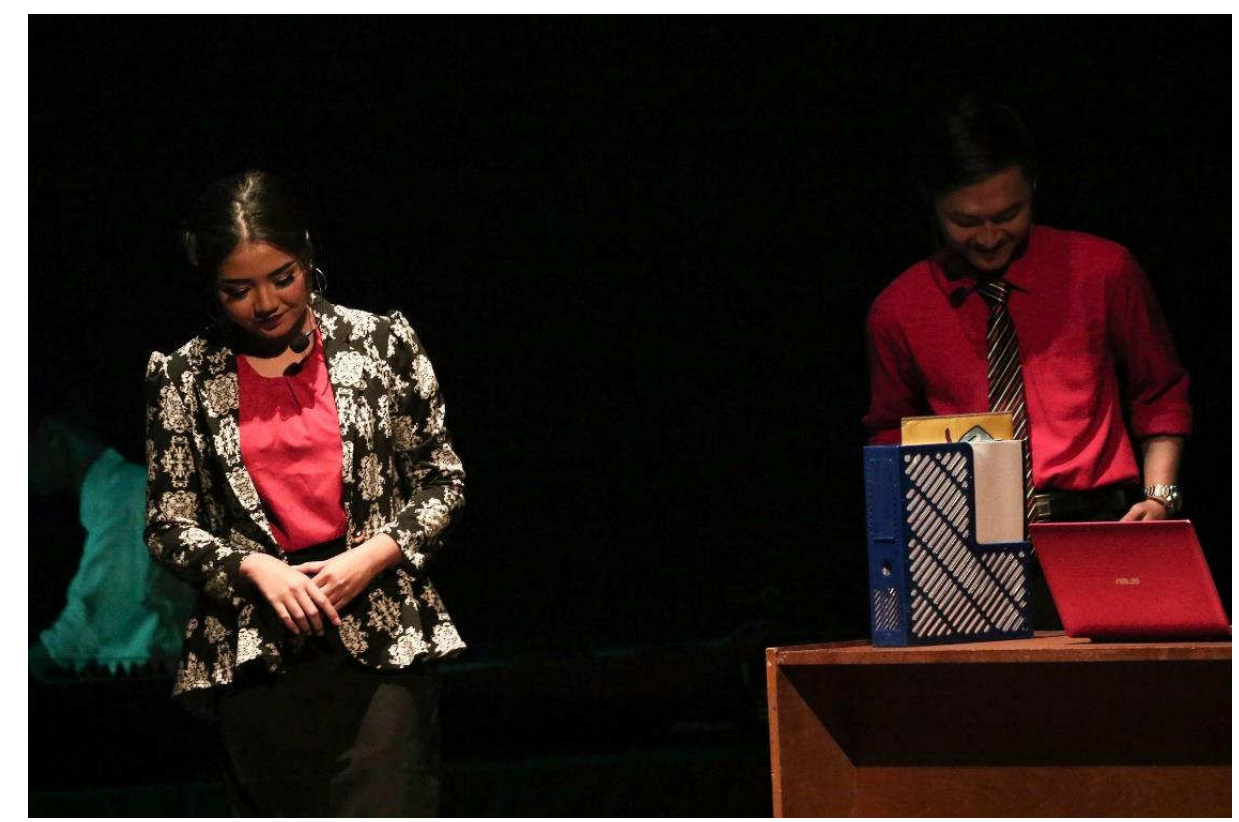

Lampiran Gambar 10. Adegan salaki saat berada di kantor bersama Risma. (Dokumentasi: Herfan Rusando, 2019)

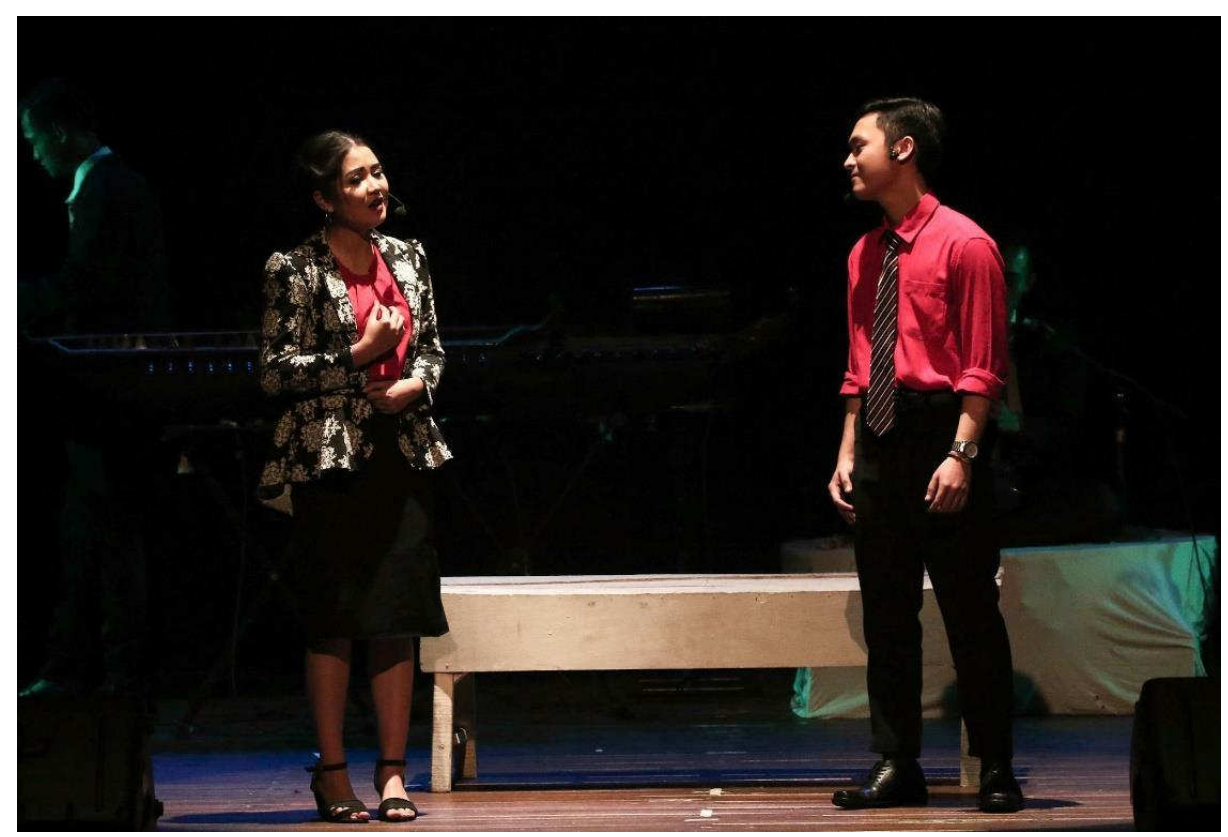

Lampiran Gambar 11. Adegan salaki akan meminang Risma. (Dokumentasi: Herfan Rusando, 2019) 


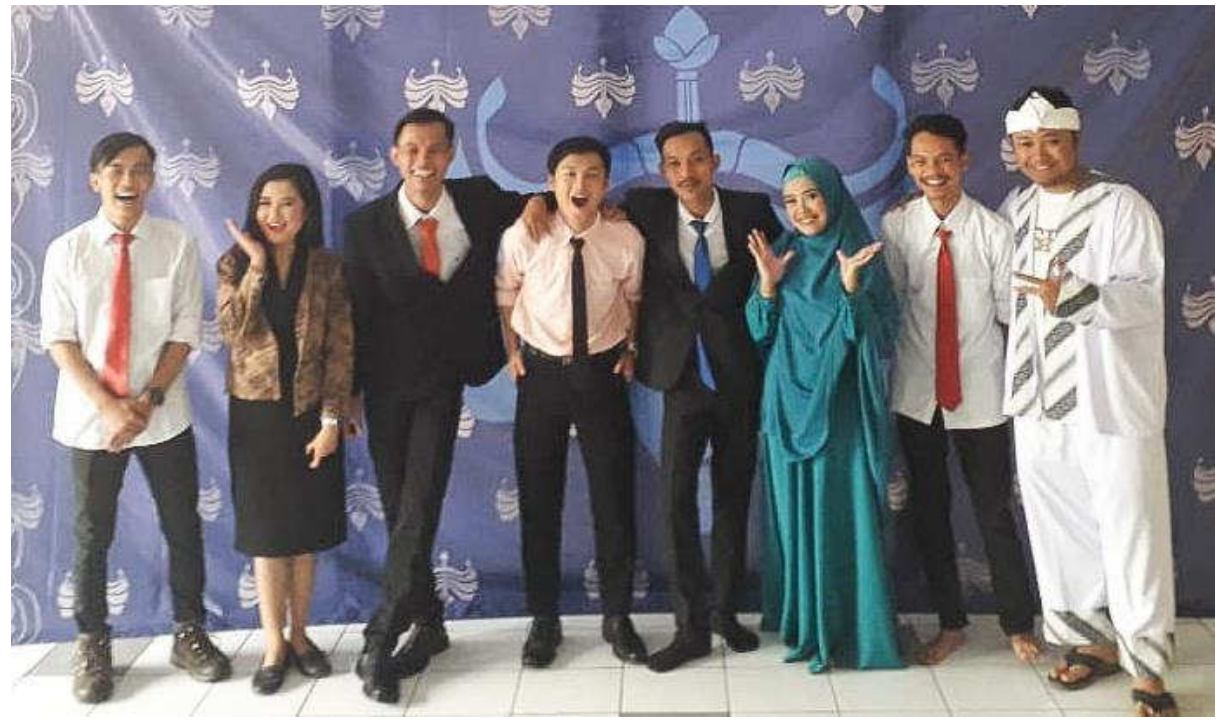

Lampiran Gambar 12. Dokumentasi gladi bersih 19 Juni 2019, penyaji bersama pendukung sajian.

(Dokumentasi: Pribadi, 2019)

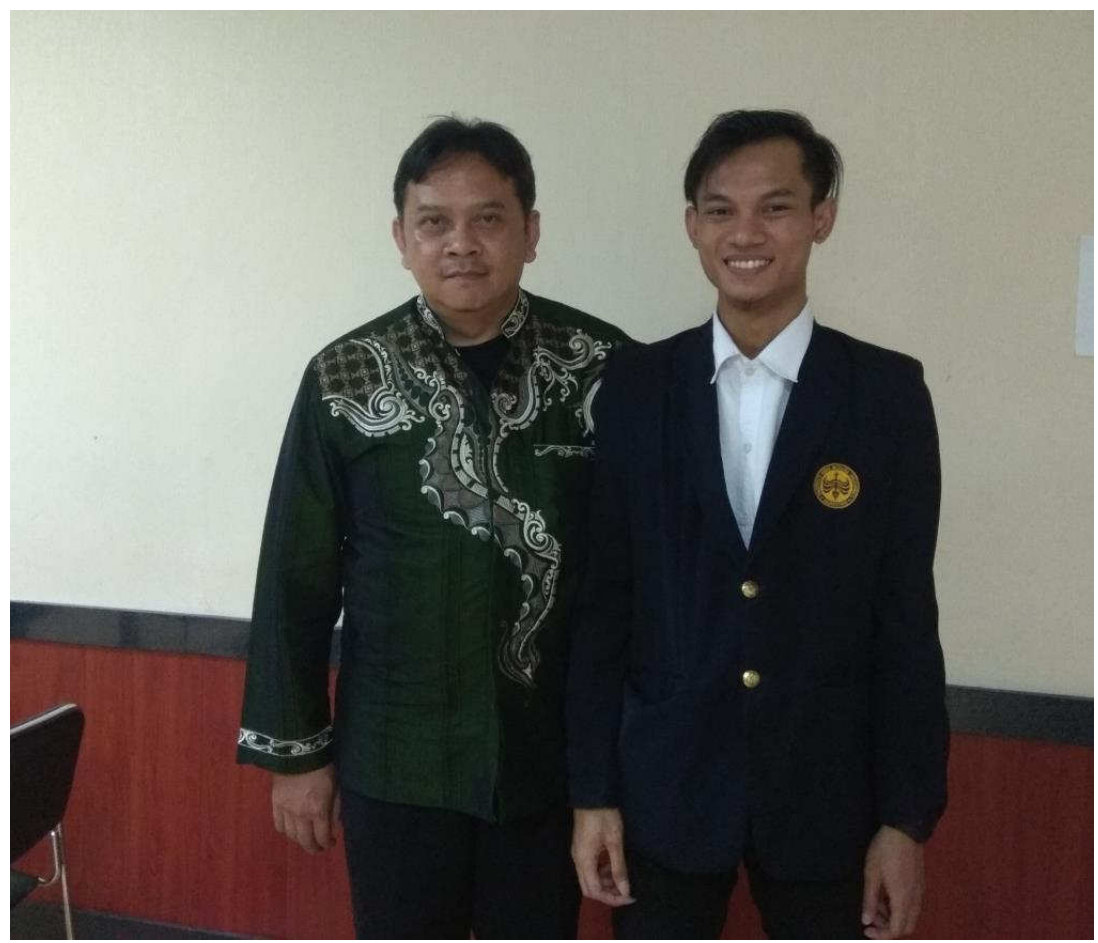

Lampiran Gambar 13. Dokumentasi penyaji dengan pembimbing (Dokumentasi: Pribadi, 2019) 


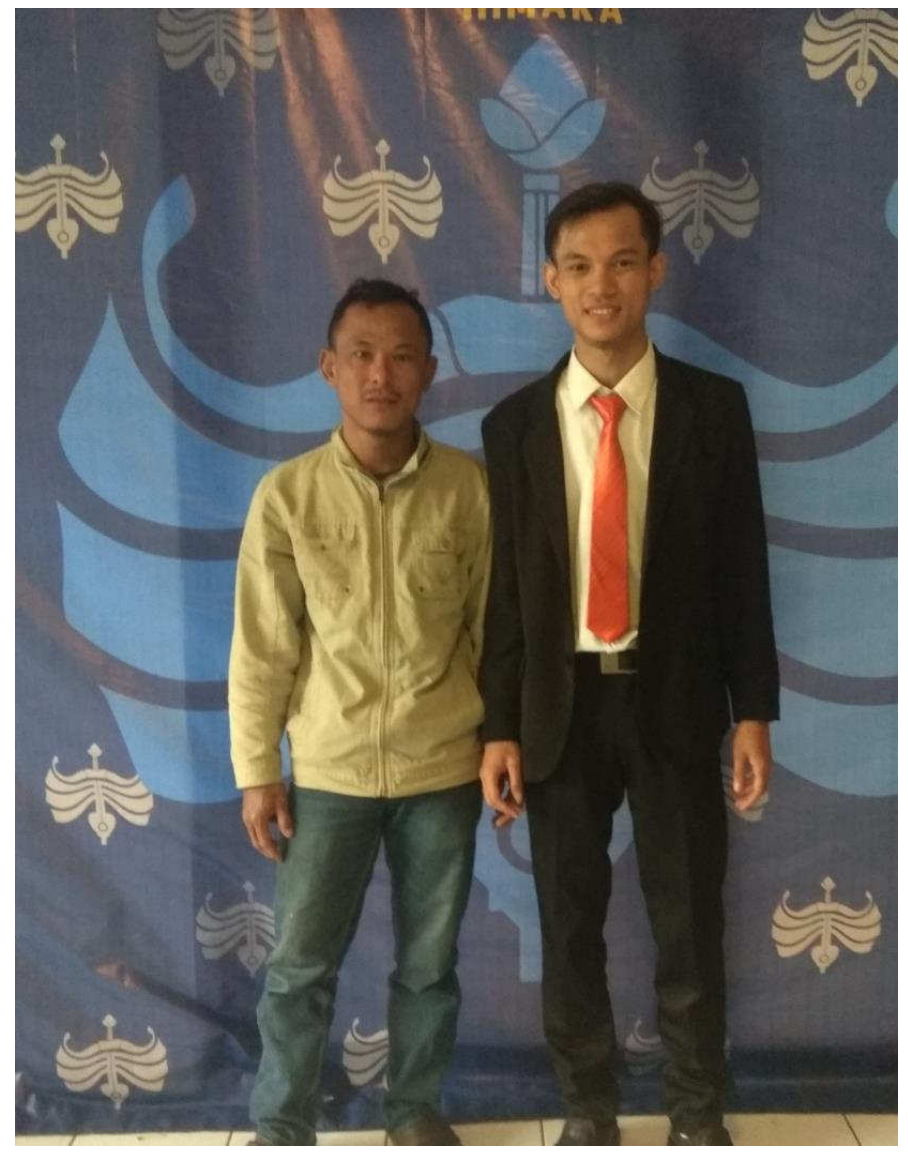

Lampiran Gambar 14. Dokumentasi penyaji bersama kaka kandung.

(Dokumentasi: Pribadi, 2019) 
Lampiran 3

\title{
FORM KEGIATAN BIMBINGAN TUGAS AKHIR MAHASISWA PROGRAM STUDI KARAWITAN FAKULTAS SENI PERTUNJUKAN INSTITUT SENI BUDAYA INDONESIA (ISBI) BANDUNG JENJANG STRATA SATU (S1)
}

\author{
Nama Mahasiswa : Agus Diantara \\ NIM \\ : 15123005 \\ Program Studi : Karawitan \\ Fakultas \\ : Seni Pertunjukan \\ Alamat \\ : Rt/Rw 04/02, Dusun II, \\ Desa Dukuhbadag, \\ Kec. Cibingbin, Kab. Kuningan
}

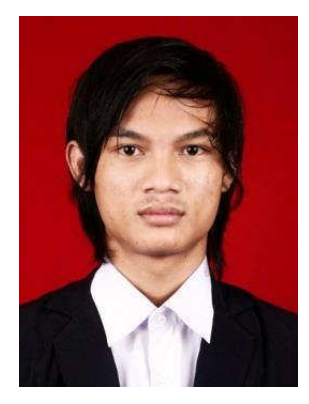

Judul Karya Seni :

\section{DUA TEU SARASA}

Dosen Pembimbing

Pembimbing I : Dr. Heri Herdini, M.Hum.

Pembimbing II $\quad$ : Asep Nugraha, M.Sn. 


\begin{tabular}{|c|c|c|c|c|}
\hline \multirow{2}{*}{ No } & \multicolumn{2}{|c|}{ WAKTU } & \multirow{2}{*}{ KEGIATAN } & \multirow{2}{*}{ CATATAN PEMBIMBING I } \\
\hline & TANGGAL & PUKUL & & \\
\hline 1 & 2 April 2019 & 16.00 & $\begin{array}{l}\text { Mendiskusikan ide / } \\
\text { konsep garap yang } \\
\text { akan disajikan untuk } \\
\text { Tugas Akhir }\end{array}$ & $\begin{array}{l}\text { cari pendukung vokal } \\
\text { yang cocok untuk } \\
\text { menjadi pemeran. }\end{array}$ \\
\hline 2 & 11 April 2019 & 16.00 & $\begin{array}{l}\text { Mendiskusikan alur } \\
\text { cerita pada naskah } \\
\text { yang akan disajikan }\end{array}$ & $\begin{array}{l}\text { explorasi lagi buat } \\
\text { jembatan gending }\end{array}$ \\
\hline 3 & 16 April 2019 & 16.00 & $\begin{array}{c}\text { Pembahasan } \\
\text { repertoar lagu yang } \\
\text { akan disajikan } \\
\text { disesuaikan dengan } \\
\text { kebutuhan naskah }\end{array}$ & $\begin{array}{c}\text { Materi lagu sudah baik, } \\
\text { pendalaman pada setiap } \\
\text { lagu harus lebih } \\
\text { dihayati }\end{array}$ \\
\hline 4 & 14 Mei 2019 & 20.00 & $\begin{array}{c}\text { Proses latihan, } \\
\text { pembahasan adegan } \\
\text { satu }\end{array}$ & $\begin{array}{c}\text { Buat musik - musik } \\
\text { untuk narrator }\end{array}$ \\
\hline 5 & 20 Mei 2019 & 20.00 & $\begin{array}{c}\text { Proses latihan } \\
\text { pembahasan adegan }\end{array}$ & $\begin{array}{c}\text { Pemeranan setiap } \\
\text { pemeran belum } \\
\text { terbangun }\end{array}$ \\
\hline
\end{tabular}




\begin{tabular}{|c|c|c|c|c|}
\hline 6 & 23 Mei 2019 & 20.00 & $\begin{array}{c}\text { Proses latihan adegan } \\
\text { dua }\end{array}$ & $\begin{array}{l}\text { Penguasaan lagu dan } \\
\text { gending lebih } \\
\text { ditingkatkan lagi }\end{array}$ \\
\hline 7 & 27 Mei 2019 & 20.00 & $\begin{array}{c}\text { Proses latihan } \\
\text { pembahasan musik } \\
\text { pengiring }\end{array}$ & $\begin{array}{c}\text { Buat musik - musik } \\
\text { jembatan untuk } \\
\text { perpindahan adegan } \\
\text { dan perpindahan laras }\end{array}$ \\
\hline 8 & 11 Juni 2019 & 20.00 & $\begin{array}{c}\text { Proses latihan } \\
\text { pembahasan adegan } \\
\text { tiga }\end{array}$ & $\begin{array}{c}\text { Adegan antara pemeran } \\
\text { dengan pemeran harus } \\
\text { lebih detail }\end{array}$ \\
\hline 9 & 12 Juni 2019 & 20.00 & $\begin{array}{l}\text { Proses latihan dari } \\
\text { awal sampai akhir }\end{array}$ & $\begin{array}{c}\text { Hapalkan lagu dan } \\
\text { jembatan pada setiap } \\
\text { lagu }\end{array}$ \\
\hline 10 & 14 Juni 2019 & 20.00 & $\begin{array}{c}\text { Bimbingan terakhir, } \\
\text { pemantapan garapan, } \\
\text { menampilkan sajian } \\
\text { dari awal sampai } \\
\text { akhir }\end{array}$ & $\begin{array}{c}\text { Tetap fokus pada setiap } \\
\text { adegan }\end{array}$ \\
\hline
\end{tabular}

Pembirmbing I

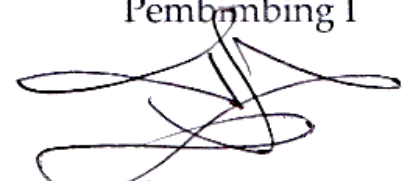

Dr. Heri Herdini, M.Hum. 


\begin{tabular}{|c|c|c|c|c|}
\hline \multirow{2}{*}{ No } & \multicolumn{2}{|c|}{ WAKTU } & \multirow{2}{*}{ KEGIATAN } & \multirow{2}{*}{$\begin{array}{c}\text { CATATAN PEMBIMBING } \\
\text { II }\end{array}$} \\
\hline & TANGGAL & PUKUL & & \\
\hline 1 & 8 April 2019 & 10.00 & Pembahasan BAB I & $\begin{array}{c}\text { Latar belakang } \\
\text { fokuskan pada bahasan } \\
\text { kacapi }\end{array}$ \\
\hline 2 & 12 April 2019 & 10.00 & Pembahasan BAB I & $\begin{array}{l}\text { Tujuan dan manfaat } \\
\text { harus sesuai dengan } \\
\text { latar belakang }\end{array}$ \\
\hline 3 & 15 April 2019 & 10.00 & Pembahasan BAB I & $\begin{array}{c}\text { Alasan pemilihan } \\
\text { landasan teori harus } \\
\text { lebih dijelaskan }\end{array}$ \\
\hline 4 & 29 April 2019 & 10.00 & Pembahasan BAB II & $\begin{array}{c}\text { Redaksi kata harus lebih } \\
\text { diperhatikan lagi }\end{array}$ \\
\hline 5 & 3 Mei 2019 & 11.00 & Pembahasan BAB II & $\begin{array}{c}\text { Tambahkan redaksi } \\
\text { pada awal pembahasan }\end{array}$ \\
\hline 6 & 9 Mei 2019 & 10.00 & Pembahasan BAB III & $\begin{array}{l}\text { Deskripsi karya lebih } \\
\text { diperjelas }\end{array}$ \\
\hline 7 & 20 Mei 2019 & 13.00 & Pembahasan BAB III & Lengkapi notasi lagu \\
\hline 8 & 3 Juni 2019 & 10.00 & Pembahasan BAB IV & Tambahkan saran \\
\hline 9 & 5 Juni 2019 & 10.00 & $\begin{array}{c}\text { Pembahasan sistem } \\
\text { penyajian }\end{array}$ & $\begin{array}{l}\text { Sesuaikan struktur } \\
\text { penyajian dengan }\end{array}$ \\
\hline
\end{tabular}




\begin{tabular}{|c|c|c|c|c|}
\hline & & & & panduan \\
\hline 10 & 7 Juni 2019 & \multirow{2}{*}{10.00} & $\begin{array}{c}\text { Kesesuaian struktur } \\
\text { penyajian, dan } \\
\text { bimbingan terakhir }\end{array}$ & $\begin{array}{c}\text { Koreksi ulang seluruh } \\
\text { tulisan }\end{array}$ \\
\hline
\end{tabular}

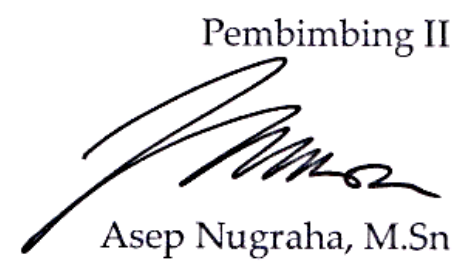




\section{Lampiran 4}

\section{CURRICULUM VITAE}

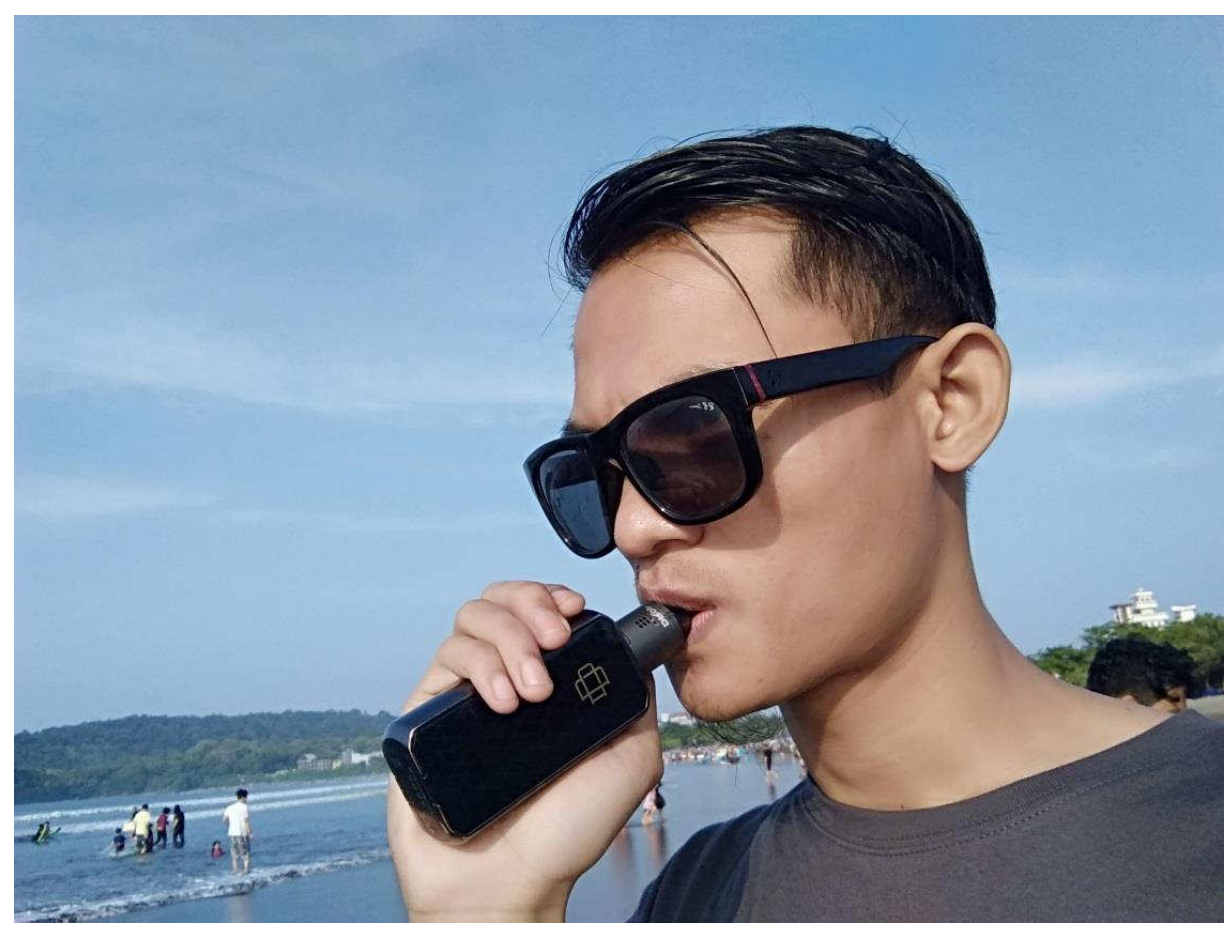

\section{A. Identitas Diri}

$\begin{array}{ll}\text { Nama } & \text { : Agus Diantara } \\ \text { NIM } & : 15123005 \\ \text { Tempat, tanggal lahir } & : \text { Kuningan, 02 Agustus } 1996 \\ \text { Jenis Kelamin } & : \text { Laki - laki } \\ \text { Agama } & : \text { Islam } \\ \text { Status } & : \text { Mahasiswa } \\ \text { Alamat } & : \text { RT/RW 02/04 Dusun 02, Desa Dukuhbadag, } \\ & \text { Kec. Cibingbin, Kab. Kuningan }\end{array}$




\section{B. Riwayat Pendidikan}

\begin{tabular}{|l|l|l|}
\hline no & Sekolah & Tahun \\
\hline 1 & SDN 1 Dukuhbadag & $2003-2009$ \\
\hline 2 & MTsN Cibingbin & $2009-2012$ \\
\hline 3 & SMAN 1 Cibingbin & $2012-2015$ \\
\hline 4 & ISBI Bandung & $2015-2019$ \\
\hline
\end{tabular}

\section{Pengalaman Berkesenian}

\begin{tabular}{|l|l|c|}
\hline no & \multicolumn{1}{|c|}{ Kegiatan } & Tahun \\
\hline 1 & $\begin{array}{l}\text { Pemusik dalam kegiataan sosialisasi } \\
\text { PON XIX Jawa Barat }\end{array}$ & 2016 \\
\hline 2 & $\begin{array}{l}\text { Pemusik dalam acara pembukaan } \\
\text { cabang olahraga Anggar PON XIXI } \\
\text { Jawa Barat }\end{array}$ & 2016 \\
\hline 3 & $\begin{array}{l}\text { Pemusik di acara hari jadi Kabupaten } \\
\text { Bandung, dihadiri Bupati dan Wakil } \\
\text { Bupati. }\end{array}$ & 2017 \\
\hline 4 & $\begin{array}{l}\text { Pemusik dalam kegiatan penyambutan } \\
\text { Walikota Bandung di Trans Studio } \\
\text { Bandung. }\end{array}$ & 2017 \\
\hline 5 & $\begin{array}{l}\text { Pemusik di acara konferensi kearifan } \\
\text { lokal kementrian sosial di Jakarta. }\end{array}$ & 2017 \\
\hline 6 & $\begin{array}{l}\text { Pemusik di acara Citarum Harum } \\
\text { penyambutan Presiden RI }\end{array}$ & 2018 \\
\hline 7 & $\begin{array}{l}\text { Pemusik di acara Internasional } \\
\text { Gamelan Festival Solo. }\end{array}$ \\
\hline
\end{tabular}

